\title{
Cosmogenic, radiogenic, and stable isotopic constraints on groundwater residence time in the Nubian Aquifer, Western Desert of Egypt
}

\author{
Leslie J. Patterson and Neil C. Sturchio \\ Department of Earth and Environmental Sciences, University of Illinois at Chicago, 845 West Taylor Street, MC 186, \\ Chicago, Illinois 60607,USA (sturchio@uic.edu)
}

\section{B. Mack Kennedy and Matthias C. van Soest}

Earth Sciences Division, Lawrence Berkeley National Laboratory, 1 Cyclotron Road, MS 90-1116, Berkeley, California 94720, USA

\section{Mohamed Sultan}

Department of Geosciences, Western Michigan University, 1187 Rood Hall, 1903 West Michigan Avenue, Kalamazoo, Michigan 49008, USA

\section{Zheng-Tian Lu}

Physics Division, Argonne National Laboratory, 9700 South Cass Avenue, Argonne, Illinois 60439, USA

\section{Bernhard Lehmann and Roland Purtschert}

Institute of Physics, University of Bern, Sidlerstrasse 5, CH-3012 Bern, Switzerland

\section{Zeinhom El Alfy}

Egyptian Geological Survey and Mining Authority, 3 Salab Salem Street, Abbassiya, Cairo, Egypt

\section{Baher El Kaliouby, Yehia Dawood, and Ali Abdallah \\ Department of Geology, Ain Shams University, Abbassiya 11566, Cairo, Egypt}

[1] Measurements of radiochlorine $\left({ }^{36} \mathrm{Cl}\right)$, radiogenic noble gases $\left({ }^{4} \mathrm{He}\right.$ and $\left.{ }^{40} \mathrm{Ar}\right)$, and stable chlorine isotope ratios were obtained to assess the residence time of groundwater in the Nubian Aquifer of the Western Desert of Egypt. Measured ${ }^{36} \mathrm{Cl} / \mathrm{Cl}$ ratios yield apparent residence times from $\sim 0.2$ to $1.2 \times$ $10^{6}$ years in the deep $(600-1200 \mathrm{~m})$ groundwater (assuming constant $\mathrm{Cl}$ ) and $\leq 0.16 \times 10^{6}$ years in the shallow $(<600 \mathrm{~m})$ groundwater. Values of $\delta^{37} \mathrm{Cl}$ in the groundwater strengthen the application of the ${ }^{36} \mathrm{Cl}$ dating method by constraining $\mathrm{Cl}$ sources and identifying groundwater mixing. Dissolved gases were measured in some of the deep groundwater samples. Measured ${ }^{4} \mathrm{He}$ concentrations indicate accumulation of radiogenic ${ }^{4} \mathrm{He}$ that is qualitatively consistent with the age progression indicated by the ${ }^{36} \mathrm{Cl} / \mathrm{Cl}$ ratios, but the flux of external ${ }^{4} \mathrm{He}$ from the underlying crust has not been quantified and is not constant throughout the aquifer. Concentrations of ${ }^{40} \mathrm{Ar}$ range from 3.3 to $6.7 \times 10^{-4} \mathrm{ccSTP} / \mathrm{g}$ and indicate excess air incorporation at recharge. Measured ${ }^{40} \mathrm{Ar} /{ }^{36} \mathrm{Ar}$ ratios do not exceed the atmospheric ratio. A two-dimensional numerical hydrodynamic transect of the aquifer was modeled from the area of the Uweinat Uplift to the northern Bahariya Oasis. Predicted groundwater velocities in the deep portion of the aquifer are $0.5-3.5 \mathrm{~m} / \mathrm{yr}$ with groundwater residence times up to $9 \times 10^{5}$ years; residence times up to $1.3 \times 10^{6}$ years are predicted in the confining shale. Aquifer properties are estimated by using the model to fit the measured ${ }^{36} \mathrm{Cl} / \mathrm{Cl}$ ratios. Under these conditions, hydrodynamic residence times are within about $30 \%$ of those calculated from ${ }^{36} \mathrm{Cl}$ when mixing of $\mathrm{Cl}^{-}$is accounted for in the highest- $\mathrm{Cl}^{-}$deep groundwaters. By mutually calibrating multiple methods (hydrodynamic, ${ }^{36} \mathrm{Cl}$, and ${ }^{4} \mathrm{He}$ ), a consistent picture of the Nubian Aquifer has emerged in which lateral flow from a 
southern recharge area dominates the deep horizons, while shallow horizons contain younger, autochthonous recharge.

Components: 11,047 words, 13 figures, 7 tables.

Keywords: chlorine-36; Egypt; groundwater.

Index Terms: 1040 Geochemistry: Radiogenic isotope geochemistry; 1655 Global Change: Water cycles (1836); 1829 Hydrology: Groundwater hydrology.

Received 18 June 2004; Revised 14 September 2004; Accepted 22 November 2004; Published 21 January 2005.

Patterson, L. J., et al. (2005), Cosmogenic, radiogenic, and stable isotopic constraints on groundwater residence time in the Nubian Aquifer, Western Desert of Egypt, Geochem. Geophys. Geosyst., 6, Q01005, doi:10.1029/2004GC000779.

\section{Introduction}

[2] The importance of studying groundwater in arid regions has increased in recent decades due to larger human populations in desert areas. At the same time, the development of technologies for measuring both stable and rare radioactive isotopes has improved our understanding of groundwater systems and groundwater age, or residence time. Cosmogenic and radiogenic nuclides have been useful in studies of several large aquifers containing very old water $(>100,000$ years) such as the Great Artesian Basin, Australia [e.g., Bentley et al., 1986b; Torgersen et al., 1991; Bethke et al., 1999], the Milk River Aquifer, Canada [Phillips et al., 1986; Lehmann et al., 1991], and the Dogger Aquifer, France [Castro et al., 1998a, 1998b]. In addition, precise measurements of $\delta^{37} \mathrm{Cl}$ have enabled the study of $\mathrm{Cl}$ isotope fractionation and solute sources in groundwaters [Eggenkamp et al., 1994; Frape et al., 1995; Groen et al., 2000; Sie and Frape, 2002; Lehmann et al., 2003].

[3] This study integrates isotopic methods of groundwater dating $\left({ }^{36} \mathrm{Cl}\right.$ and $\left.{ }^{4} \mathrm{He}\right)$ with measurements of stable $\mathrm{Cl}$ isotope ratios and the chemical compositions of groundwater from the Nubian Aquifer, Western Desert, Egypt. This aquifer has several complicating factors in determining flow patterns, residence times, and solute transport, thus providing a good location for testing the rigor of the ${ }^{36} \mathrm{Cl}$ method for groundwater dating. Close agreement between hydrodynamic and isotopic methods indicates that ${ }^{36} \mathrm{Cl}$ dating is robust for samples having low $\mathrm{Cl}^{-}$concentration $(<50 \mathrm{mg} / \mathrm{L})$, but radiogenic accumulation of ${ }^{4} \mathrm{He}$ and ${ }^{40} \mathrm{Ar}$ does not provide a quantitative measure of residence time in the Nubian Aquifer. A conceptual model of paleorecharge, groundwater flow and solute transport is presented that accounts for the ${ }^{36} \mathrm{Cl}$ distri- bution as well as the stable isotopic composition of dissolved $\mathrm{Cl}^{-}$.

\section{Geologic Setting}

[4] The Nubian Aquifer, underlying the northeastern portion of the Sahara Desert, covers approximately 2 million $\mathrm{km}^{2}$ and has been estimated to contain at least $50,000 \mathrm{~km}^{3}$ of groundwater [Thorweihe, 1990] (Figure 1). It rests unconformably upon a Proterozoic granite basement that outcrops to the west, south, and east, and slopes northward. The basement is elevated in the center creating two basins: the Dakhla Basin underlies the Western Desert of Egypt and eastern Libya, while the Kufra Basin underlies southeastern Libya, northeastern Chad and northwestern Sudan. The Dakhla Basin is bounded to the north by the saline waters of the Northwestern Basin and to the east by the Kharga Uplift that separates it from the Upper Nile Platform (UNP), a hydraulically unconnected, uplifted area with a different sedimentary history [Thorweihe, 1990].

[5] The water-bearing portion of the Dakhla Basin is composed of four hydraulically connected horizons of Paleozoic and Mesozoic epicontinental sandstone (the "Nubian sandstone") separated by thin layers of shale (Figure 2). The aquifer ranges from $400 \mathrm{~m}$ to nearly $3000 \mathrm{~m}$ in thickness [Hesse et al., 1987]; hydraulic conductivity is $10^{-6}$ to $10^{-5} \mathrm{~m} \mathrm{sec}^{-1}$ overall, although the confining layers thicken northward and restrict groundwater flow [Brinkmann et al., 1987]. The Nubian sandstone outcrops across the southern portion of the basin, but north of $25^{\circ} \mathrm{N}$ thick marine shales of Paleocene age confine the aquifer. Artesian discharge occurs at oases, where faults and folds in the basement and aquifer horizons have caused localized uplift and erosion of the confining beds. 


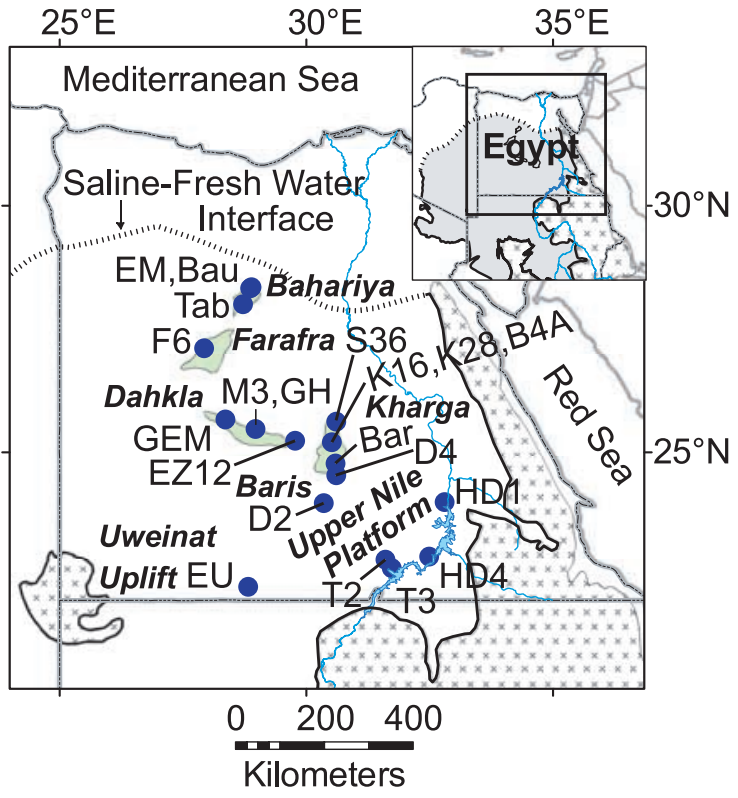

Figure 1. Location map of the Nubian Aquifer, northeast Africa. Shaded region of inset map indicates area of the aquifer.

The piezometric surface indicates that groundwater flows primarily southwest to northeast [Ball, 1927] connecting (in order) the Dakhla, Farafra, and Bahariya oases along a flowpath. A lesser component of flow travels east from the Dakhla Oasis to the Kharga Oasis (Figure 3).

[6] The climate of the Western Desert is hyperarid, with annual rainfall less than $20 \mathrm{~mm} / \mathrm{yr}$ and less than $5 \mathrm{~mm} / \mathrm{yr}$ over much of the area. The Dakhla Basin receives no continuous surface recharge today although it may receive baseflow from adjacent groundwater in the Kufra Basin. Recharge did occur during the wetter climate that prevailed at various times during at least the past 450 kyr BP, with the most recent periods occurring between 9.5 to $4.5 \mathrm{kyr} \mathrm{BP}$ and 25 to $40 \mathrm{kyr}$ BP [Pachur et al., 1987; Hesse et al., 1987]. During the pluvial periods, groundwater recharge occurred both at the outcrops of the Nubian Sandstone (particularly at wadis [Hesse et al., 1987] and in mountainous areas) and as leakage through the confining layers north of the 25th parallel. Thus both local and large-scale regional flow occurs in the Nubian Aquifer. Widespread local recharge is represented in the shallow horizons of the aquifer where measurable ${ }^{14} \mathrm{C}$ exists [Sonntag, 1984; Brinkmann et al., 1987]. In contrast deeper water represents baseflow from remote recharge areas to the south, has longer residence times, and dominates groundwater movement during arid periods [Brinkmann et al., 1987]. Fluctuations in the water table and groundwater flow caused by oscillating recharge conditions complicate investigations of flow over timescales of millennia [Hesse et al., 1987], particularly in the upper horizons of the aquifer. The mixing of waters of different ages discharging at oases can cause disagreement between
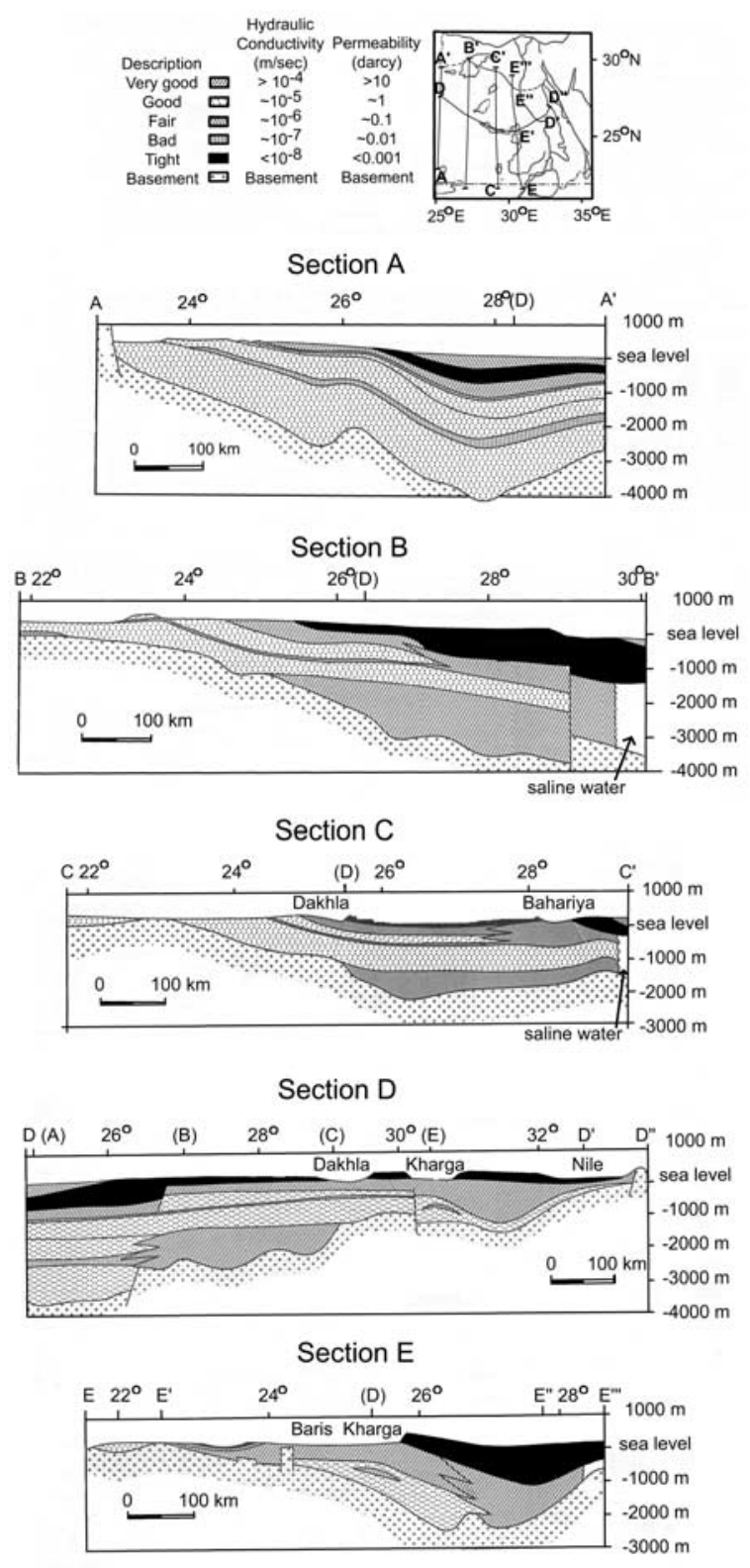

Figure 2. Cross sections of the Dakhla Basin, Egypt. Thickness, extent, and hydraulic conductivity of the four major water-bearing sandstone horizons and the interbedded and overlying shales are indicated (modified from Hesse et al. [1987]). 


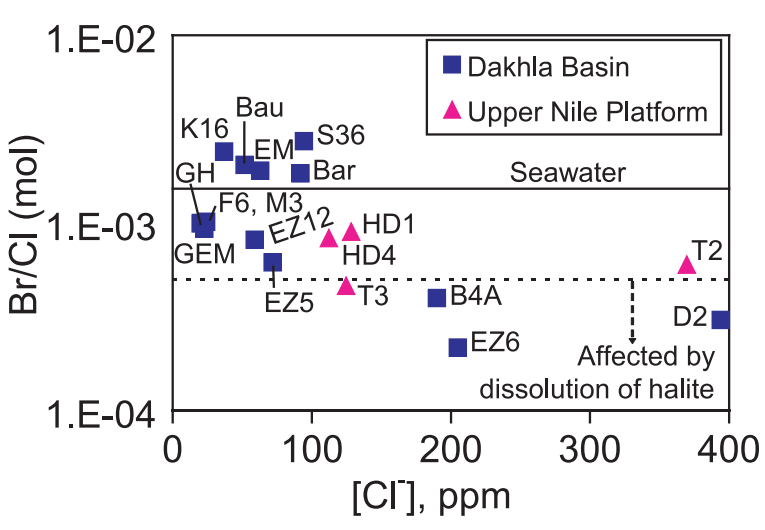

Figure 3. $\mathrm{Br} / \mathrm{Cl}$ ratios versus $\mathrm{Cl}^{-}$concentrations.

residence times calculated by different techniques [Hesse et al., 1987].

\section{Methods}

\subsection{Field Methods}

[7] Water samples were taken from established wells at East Uweinat and the Dakhla, Kharga, Baris, Farafra and Bahariya oases in 1994 and 2002, and in the Upper Nile Platform in 2000 (Figure 1). Stagnant wells were pumped or flowed (if artesian) until water temperature stabilized before sampling. Two 250-mL polyethylene bottles of each sample were filled for ionic analysis, one of which was filtered with a $0.45 \mu \mathrm{m}$ polypropylene syringe filter in the field. Samples for noble gas isotopic analysis were collected in crimp-sealed $0.25^{\prime \prime}$-i.d. Cu tubing.

\subsection{Laboratory Methods}

[8] Chloride and bromide concentrations were measured by ion chromatography (IC), except in samples having bromide below detection by IC, for which bromide concentrations were measured by ICP-MS. Total alkalinity was measured by titration with $0.1 \mathrm{M} \mathrm{HCl}$ using an autotitrator. Oxygen isotope ratios were measured by $\mathrm{CO}_{2}$ equilibration [Epstein and Mayeda, 1953]. Hydrogen isotope ratios were measured by either zinc reduction (1994 sample set) [Coleman et al., 1982] or $\mathrm{H}_{2}$ equilibration (2000 and 2002 sample sets) [Coplen et al., 1991]. Stable $\mathrm{Cl}$ isotopes were measured by $\mathrm{AgCl}$ precipitation and conversion to methyl chloride [Eggenkamp, 1994].

[9] Samples were prepared for accelerator mass spectrometry (AMS) analysis of ${ }^{36} \mathrm{Cl}$ by precipitation and purification of $\mathrm{AgCl}$. Chlorine-36 was measured at the PRIME Laboratory of Purdue University [Elmore and Phillips, 1987]. Noble gas concentrations and isotope ratios were measured by mass spectrometry. The ${ }^{4} \mathrm{He} /{ }^{36} \mathrm{Ar}$ ratio is determined directly in the same manner as isotope ratios by analyzing an aliquot of the sample and normalizing the peak height of the most abundant isotope of each noble gas $\left({ }^{4} \mathrm{He},{ }^{22} \mathrm{Ne},{ }^{36} \mathrm{Ar},{ }^{84} \mathrm{Kr}\right.$, and $\left.{ }^{132} \mathrm{Xe}\right)$ to that of ${ }^{36} \mathrm{Ar}$. The ${ }^{36} \mathrm{Ar}$ peak height is converted to a gas concentration $\left(\mathrm{cm}^{3} \mathrm{STP}\right)$ using a conversion factor determined from the measurement of a calibrated air standard. The ${ }^{4} \mathrm{He}$ concentration is calculated from the measured ${ }^{4} \mathrm{He} /{ }^{36} \mathrm{Ar}$ ratio and the ${ }^{36} \mathrm{Ar}$ concentration. We estimate a $\pm 10 \%$ uncertainty in the ${ }^{36} \mathrm{Ar}$ concentration. For further details, see Hiyagon and Kennedy [1992].

\section{Results and Discussion}

\subsection{Chemical and Isotopic Characterization of Nubian Aquifer Waters}

[10] All horizons and a wide range of depths within the aquifer are represented in the samples (Table 1). Nubian Aquifer water is strongly depleted in ${ }^{18} \mathrm{O}$ and $\mathrm{D}$ relative to modern precipitation in the region (Table 2); in the Dakhla Basin, $\delta^{18} \mathrm{O}$ ranges from -11.2 to $-8.1 \%$, while $\delta \mathrm{D}$ ranges from -83.8 to $-75.0 \%$. The Upper Nile Platform samples are slightly less depleted with $\delta^{18} \mathrm{O}$ ranging from -10.2 to $-8.1 \%$ and $\delta \mathrm{D}$ ranging from -78.0 to $-62.6 \%$. These values are consistent with the progressive isotopic depletion of groundwaters across the Sahara that has been attributed to an Atlantic moisture source of recharge during intermittent pluvial periods for at least the past $450 \mathrm{kyr}$ [Sonntag et al., 1978; Joseph et al., 1992; Sultan et al., 1997].

[11] Chloride concentrations range over one order of magnitude (from 20.1 to $394 \mathrm{mg} / \mathrm{L}$ ) and generally decrease with depth (Table 2). The vertical salinity gradient in the Nubian Aquifer is typical for arid regions and is attributed to evaporation that concentrates meteoric $\mathrm{Cl}^{-}$ [Shata, 1982; Shehata and Al-Ruwaih, 1999]. Excepting the northern Bahariya samples (Bau and $\mathrm{EM}), \mathrm{Cl}^{-}$concentrations in the deep (C/D horizons) samples are consistently low ( $\sim 23 \mathrm{mg} / \mathrm{L})$ indicating little or no addition of subsurface $\mathrm{Cl}^{-}$from the Dakhla Oasis to southern Bahariya. $\mathrm{Cl}^{-}$is more concentrated in the $\mathrm{C}$ and $\mathrm{D}$ horizons in northern Bahariya and all horizons at Kharga, as well as in the shallow samples of the Upper Nile Platform. 
Table 1. Well Depths and Stratigraphic Horizons of Nubian Aquifer Wells Sampled

\begin{tabular}{|c|c|c|c|c|c|c|c|}
\hline \multirow[b]{2}{*}{ Well } & \multirow[b]{2}{*}{ Label } & \multirow[b]{2}{*}{ Total Well Depth, m } & \multirow[b]{2}{*}{ Horizon(s) } & \multicolumn{4}{|c|}{ Horizon, Depth Below Surface } \\
\hline & & & & $\mathrm{A}, \mathrm{m}$ & $\mathrm{B}, \mathrm{m}$ & $\mathrm{C}, \mathrm{m}$ & $\mathrm{D}, \mathrm{m}$ \\
\hline \multicolumn{8}{|c|}{ Upper Nile Platform } \\
\hline T2 (Kalabsha) & $\mathrm{T} 2$ & 187 & - & - & - & - & - \\
\hline T3 (Mubarak) & T3 & 223 & - & - & - & - & - \\
\hline HD1 (Kurkur) & HD1 & 200 & - & - & - & - & - \\
\hline HD4 (El Sabouh) & HD4 & 192 & - & - & - & - & - \\
\hline \multicolumn{8}{|c|}{ Uweinat Uplift } \\
\hline East Uweinat & EU & - & - & - & - & - & - \\
\hline \multicolumn{8}{|c|}{ Dakhla Oasis } \\
\hline Mut $3(02)$ & M3 & 1020 & $\mathrm{D}$ & $40-150$ & $198-503$ & $536-670$ & $688-1020$ \\
\hline Mut 3 (94) & M3 & 1020 & $\mathrm{D}$ & $40-150$ & $198-503$ & $536-670$ & $688-1020$ \\
\hline El Zayat 12 & $\mathrm{EZ12}$ & 720 & - & - & - & - & - \\
\hline El Zayat 5 & EZ5 & 618 & $\mathrm{C}$ & $0-212$ & $218-400$ & $400-618$ & - \\
\hline El Zayat 6 & EZ6 & 355 & $\mathrm{~B}$ & $0-212$ & $218-355$ & - & - \\
\hline Gharb El Mohoub & GEM & 1200 & - & - & - & - & - \\
\hline Gum Horia & $\mathrm{GH}$ & 1200 & - & - & - & - & - \\
\hline \multicolumn{8}{|c|}{ Kharga/Baris Oases } \\
\hline Baris & Bar & 600 & - & - & - & - & - \\
\hline Bulaq 4A & B4A & 387 & $\mathrm{~A} / \mathrm{B}$ & $50-120$ & $135-387$ & - & - \\
\hline D2 (D. El Arb.) & $\mathrm{D} 2$ & 500 & - & - & - & - & - \\
\hline D4 (El Kass) & D4 & - & - & - & - & - & - \\
\hline Kharga 16 & K16 & 687 & $\mathrm{~B} / \mathrm{C}$ & $80-312$ & $325-405$ & $405-687$ & - \\
\hline Kharga 28 & K28 & 295 & $\mathrm{~A} / \mathrm{B}$ & $50-200$ & $210-295$ & - & - \\
\hline Sherka 36 & $\mathrm{~S} 36$ & 750 & - & - & - & - & - \\
\hline \multicolumn{8}{|c|}{ Farafra Oasis } \\
\hline Farafra 6 & F6 & 800 & $\mathrm{C} / \mathrm{D}$ & $140-230$ & $330-560$ & $570-635$ & $635-800$ \\
\hline Farafra 6 & F6 & 800 & $\mathrm{C} / \mathrm{D}$ & $140-230$ & $330-560$ & $570-635$ & $635-800$ \\
\hline \multicolumn{8}{|c|}{ Bahariya Oasis } \\
\hline Bauti & Bau & 1200 & - & - & - & - & - \\
\hline El Mattar & EM & 1000 & - & - & - & - & - \\
\hline El Mattar & EM & 1000 & - & - & - & - & - \\
\hline Tablamoun & $\mathrm{Tab}$ & 1100 & $\mathrm{C} / \mathrm{D}$ & $0-250$ & $250-450$ & $470-890$ & $890-1100$ \\
\hline
\end{tabular}

[12] $\mathrm{Br} / \mathrm{Cl}$ molar ratios range from 3.0-27 $\times 10^{-4}$, a relatively small variation around the seawater $\mathrm{Br} /$ $\mathrm{Cl}$ ratio of $16 \times 10^{-4}$ (Figure 3). Although $\mathrm{Br} / \mathrm{Cl}$ ratios in precipitation and cyclic salts can vary widely, ratios $<5 \times 10^{-4}$ may be used to infer dissolution of halite in groundwaters [e.g., Herczeg et al., 1991; Davis et al., 1998b]. Four water samples have such low $\mathrm{Br} / \mathrm{Cl}$ ratios (EZ6, B4A, $\mathrm{D} 2$, and $\mathrm{T} 3$ ); these are relatively shallow samples, from 223 to $500 \mathrm{~m}$ below the surface. During the semi-arid conditions of paleorecharge in the Western Desert, infrequent recharge events and the concentration of solutes by evaporation could have caused halite accumulation above the water table. The concentration of solutes during dry periods may have caused precipitation of the less-soluble $\mathrm{Cl}-$ salts while $\mathrm{Br}$ - continued to be flushed through the system. As the climate became wetter, halite may have been dissolved and flushed into the top few hundred meters of the aquifer, causing the low $\mathrm{Br} / \mathrm{Cl}$ ratios in the shallow horizons. Low $\mathrm{Br} / \mathrm{Cl}$ ratios in deserts due to infrequent recharge and the dissolution of salty dust have been reported elsewhere [Davis et al., 1998b].

[13] The $\delta^{37} \mathrm{Cl}$ values of the Dakhla Basin waters range from -1.0 to $+0.51 \%$, while the $\delta^{37} \mathrm{Cl}$ values of the Upper Nile Platform waters are more depleted, ranging from -1.16 to $-0.66 \%$ (Table 2). These values are within the $0 \pm 2 \%$ range measured in groundwaters in other sedimentary basins [Clark and Fritz, 1997; Weaver, 2000]. Three endmembers in the Nubian Aquifer can be identified on the basis of $\mathrm{Cl}^{-}$concentration and isotopic 
Table 2. Chemical and Isotopic Compositions of Nubian Aquifer Groundwater Samples

\begin{tabular}{|c|c|c|c|c|c|c|c|}
\hline Sample & $\mathrm{Cl}^{-}, \mathrm{mg} / \mathrm{L}$ & $\mathrm{Br} / \mathrm{Cl}$, mol. ratio & $\delta^{37} \mathrm{Cl}_{\text {SMOC }}, \%$ & ${ }^{36} \mathrm{Cl} / \mathrm{Cl}\left(\times 10^{-15}\right)$ & ${ }^{36} \mathrm{Cl}$ atoms $/ \mathrm{L}\left(\times 10^{6}\right)$ & $\delta^{18} \mathrm{O}$ & $\delta \mathrm{D}$ \\
\hline \multicolumn{8}{|c|}{ Upper Nile Platform } \\
\hline $\mathrm{T} 2$ & 370 & $6.0 \times 10^{-4}$ & -0.93 & $122( \pm 5)$ & $770( \pm 36)$ & -9.1 & -76.3 \\
\hline $\mathrm{T} 3$ & 125 & $4.6 \times 10^{-4}$ & -1.16 & $120( \pm 5)$ & $260( \pm 12)$ & -10.2 & -78 \\
\hline HD1 & 128 & $9.0 \times 10^{-4}$ & -0.66 & $100( \pm 5)$ & $220( \pm 11)$ & -8.7 & -70.1 \\
\hline HD4 & 112 & $8.3 \times 10^{-4}$ & -0.93 & $131( \pm 6)$ & $250( \pm 13)$ & -8.1 & -62.6 \\
\hline \multicolumn{8}{|c|}{ Uweinat Uplift } \\
\hline EU & 209 & - & -0.23 & $156( \pm 7.0)$ & $554( \pm 27)$ & -10.3 & -77 \\
\hline \multicolumn{8}{|c|}{ Dakhla Oasis } \\
\hline M3 (02) & 20.9 & $1.0 \times 10^{-3}$ & -0.47 & $88.5( \pm 5.0)$ & $31.4( \pm 1.9)$ & -11.0 & -82.8 \\
\hline M3 (94) & 21.8 & - & - & - & - & -11.4 & -80.0 \\
\hline EZ12 & 59 & $8.1 \times 10^{-4}$ & -0.64 & $72.7( \pm 2.7)$ & $72.9( \pm 3.1)$ & -10.9 & -81.7 \\
\hline EZ 5 & 72 & $6.2 \times 10^{-4}$ & - & $79( \pm 6)$ & $97( \pm 8)$ & -10.7 & -77.0 \\
\hline EZ 6 & 205 & $2.2 \times 10^{-4}$ & - & $92( \pm 2)$ & $320( \pm 10)$ & -10.4 & -72.0 \\
\hline GEM & 22.9 & $9.3 \times 10^{-4}$ & -0.51 & $81.3( \pm 3.2)$ & $31.6( \pm 1.4)$ & -11.2 & -83.8 \\
\hline $\mathrm{GH}$ & 20.1 & $9.9 \times 10^{-4}$ & -0.45 & $76.5( \pm 3.4)$ & $26.1( \pm 1.3)$ & -11.1 & -81.2 \\
\hline \multicolumn{8}{|c|}{ Kharga/Baris Oases } \\
\hline Bar & 92 & $1.8 \times 10^{-3}$ & -0.25 & $45.6( \pm 2.1)$ & $71.3( \pm 3.6)$ & -10.8 & -81.4 \\
\hline B4A & 190 & $4.4 \times 10^{-4}$ & - & $228( \pm 6)$ & $740( \pm 24)$ & -10.6 & -80.0 \\
\hline D2 & 394 & $3.0 \times 10^{-4}$ & -1.00 & $89( \pm 8)$ & $600( \pm 55)$ & -10.2 & -79 \\
\hline D4 & 167 & - & -0.91 & $99( \pm 6)$ & $280( \pm 18)$ & -10.5 & -80.6 \\
\hline K16 & 37 & $2.4 \times 10^{-3}$ & - & $53( \pm 4)$ & $33( \pm 3)$ & -11.0 & -81.0 \\
\hline K28 & 59 & - & - & - & - & -10.5 & -79.0 \\
\hline S36 & 94.5 & $2.7 \times 10^{-3}$ & +0.36 & $12.2( \pm 5.0)$ & $22.5( \pm 8.2)$ & -11.0 & -81.6 \\
\hline \multicolumn{8}{|c|}{ Farafra Oasis } \\
\hline F6 (02) & 24.1 & $1.0 \times 10^{-3}$ & -0.55 & $65.3( \pm 3.5)$ & $26.7( \pm 1.5)$ & -10.3 & -78.9 \\
\hline F6 (94) & 21 & - & - & $65( \pm 3)$ & $23( \pm 1)$ & -10.1 & -75.0 \\
\hline \multicolumn{8}{|c|}{ Bahariya Oasis } \\
\hline $\mathrm{Bau}$ & 51.8 & $2.0 \times 10^{-3}$ & +0.43 & $19.6( \pm 1.5)$ & $17.2( \pm 1.4)$ & -10.8 & -81.3 \\
\hline EM (02) & 63 & $1.9 \times 10^{-3}$ & +0.51 & $16.0( \pm 12)$ & $17.1( \pm 12.8)$ & -10.8 & -81.0 \\
\hline EM (94) & 58 & - & - & - & - & -10.8 & -76 \\
\hline $\mathrm{Tab}$ & 23 & - & - & $33( \pm 2)$ & $12.9( \pm 0.8)$ & -10.5 & -77 \\
\hline
\end{tabular}

composition (Figure 4). The deep, low- $\mathrm{Cl}^{-}$samples from Dakhla and Farafra have a $8^{37} \mathrm{Cl}$ value of $\sim-0.5 \%$ with no significant variation (Group 1). Although meteoric $\delta^{37} \mathrm{Cl}$ values may vary, the consistently low $\mathrm{Cl}^{-}$concentrations along with the uniform $\delta^{37} \mathrm{Cl}$ values in this group suggest that $-0.5 \%$ is the average isotopic composition of paleometeoric $\mathrm{Cl}^{-}$in the water that recharged the deep portion of the aquifer. The $\delta^{37} \mathrm{Cl}$ of Group 1 and EZ12 are within $0.2 \%$ of each other indicating that the dissolved $\mathrm{Cl}^{-}$of these samples shares a single source but has varying concentrations.

[14] The more concentrated samples have two isotopic end-members: a depleted end-member having $\delta^{37} \mathrm{Cl} \sim-1 \%$, represented by the shallow Upper Nile Platform samples and the two southern Kharga samples (Group 2), and an enriched endmember having $\delta^{37} \mathrm{Cl} \sim+0.5 \%$ as seen in $\mathrm{S} 36$ and the northern Bahariya (Bau and EM) samples
(Group 3). The depleted $\delta^{37} \mathrm{Cl}$ values of Group 2 may represent an unaltered meteoric value of more recent (late Pleistocene) recharge, or a combination of meteoric chloride and near-surface halite. However, Group 2 is depleted in ${ }^{37} \mathrm{Cl}$, whereas halite is normally enriched in ${ }^{37} \mathrm{Cl}$ [Eggenkamp et al., 1995]. Diffusional fractionation of $\mathrm{Cl}^{-}$may occur as $\mathrm{Cl}^{-}$diffuses downward along the vertical concentration gradient, resulting in depleted values in the aquifer. Solute transport occurring preferentially by diffusion in the Upper Nile Platform is consistent with the presence of a thick (up to $500 \mathrm{~m}$ ) confining layer characterized by a higher proportion of low-permeability shales than is found in the Dakhla Basin [Thorweihe, 1990; Hesse et al., 1987].

[15] The enriched $\delta^{37} \mathrm{Cl}$ values of Group 3 are found in three downgradient samples. At northern Bahariya (EM, Bau) the source of additional $\mathrm{Cl}^{-}$ 


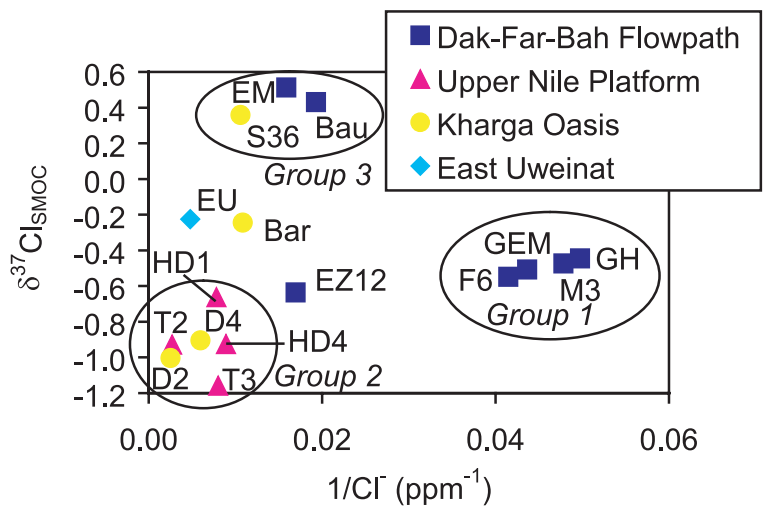

Figure 4. Concentrations $\delta^{37} \mathrm{Cl}_{\mathrm{SMOC}}$ versus $1 / \mathrm{Cl}^{-}$. Three end members are apparent: Group 1, the dilute $\left(<25 \mathrm{mg} / \mathrm{L} \mathrm{Cl}^{-}\right)$samples with a $\delta^{37} \mathrm{Cl} \sim-0.5 \%$; Group 2 , the more concentrated $\left(125-394 \mathrm{mg} / \mathrm{L} \mathrm{Cl}^{-}\right)$shallow, young samples from the Upper Nile Platform and south Baris Oasis with a $\delta^{37} \mathrm{Cl} \sim-1.0 \%$; and Group 3, with intermediate $\mathrm{Cl}^{-}$concentrations $\left(50-100 \mathrm{mg} / \mathrm{L} \mathrm{Cl}^{-}\right)$ and $\delta^{37} \mathrm{Cl} \sim+0.5 \%$.

has $\delta^{37} \mathrm{Cl}$ between +0.5 and $+1.1 \%$, suggesting a rock source; $\delta^{37} \mathrm{Cl}$ values of +0.4 to $7.5 \%$ o have been measured in silicates [Weaver, 2000] and fluid inclusions in igneous, mafic rocks may be enriched up to $+4.0 \%$ [Frape et al., 1995]. Shale beds thicken significantly just downgradient from northern Bahariya, and the saline-freshwater interface is approximately $130 \mathrm{~km}$ north of the EM and Bau wells (Figures 1 and 2) [Research Institute for Groundwater, 1988]. Groundwater velocity is likely slowed by both of these factors, increasing rockwater contact and the movement of $\mathrm{Cl}^{-}$by diffusion. Isotopically enriched $\mathrm{Cl}^{-}$may be leaching and diffusing from silicates within the marine shale, or residual saline pore fluids from a seawater incursion may have fractionated due to the faster diffusion of ${ }^{35} \mathrm{Cl}$, increasing $8^{37} \mathrm{Cl}$ values in shale pore waters. At Kharga the increase in salinity has been attributed to a lower sand percentage relative to other Western Desert oases and to the presence of some $\mathrm{Cl}^{-}$containing clays [Attia, 2001], and diffusion of $\mathrm{Cl}^{-}$from these clays may explain the enriched $8^{37} \mathrm{Cl}$ value at $\mathrm{S} 36$.

[16] The values of $\delta^{37} \mathrm{Cl}$ in the $\mathrm{A}, \mathrm{B}$ and $\mathrm{C}$ horizons at Kharga and East Uweinat overlap those of Groups 1 and 3. Bar is also slightly enriched and concentrated relative to Group 1, but the depth of that well and its $\mathrm{Br} / \mathrm{Cl}$ ratio preclude surface halite dissolution. The EU sample is from a relatively shallow (depth to basement $<600 \mathrm{~m}$ ) well in an unconfined area; its $\delta^{37} \mathrm{Cl}$ value is slightly $(<0.3 \%$ ) enriched relative to Group 1 and may represent an unchanged meteoric value or a meteoric value slightly enriched by halite dissolution.

[17] The distribution of $\mathrm{Cl}^{-}$and $\delta^{37} \mathrm{Cl}$ values in the Western Desert indicates that although subsurface addition of $\mathrm{Cl}^{-}$is apparent in the Group 3 samples, the sole source of $\mathrm{Cl}^{-}$for most samples is meteoric. A common model of the Nubian Aquifer is suggested by the distribution of stable $\mathrm{Cl}^{-}$isotopes, $\mathrm{Cl}^{-}$concentrations, and $\mathrm{Br} / \mathrm{Cl}$ ratios: deep, dilute and upgradient (Dakhla, Farafra, Baris) samples demonstrate the predominance of wellflushed meteoric $\mathrm{Cl}^{-}$; shallow samples show the effects of evaporative concentration and possible diffusion of $\mathrm{Cl}^{-}$; and where subsurface addition of $\mathrm{Cl}^{-}$occurs, it is localized in areas with thick shale beds or increased clay percentages in the aquifer matrix.

\subsection{Groundwater Model of the Nubian Aquifer}

[18] Groundwater models were constructed using Basin2 (release 5.0) and B2plot [Bethke et al., 2002]. Basin 2 uses a finite difference grid to predict two-dimensional groundwater flow in sedimentary basins, and B2plot displays the numerical results in graphical form. The model presented here represents the Nubian Aquifer pre-1950, before intense development of the aquifer began lowering potentiometric surface; it is assumed that steady state simulations adequately represent flow regime at that time.

[19] Transect F-F' is $743 \mathrm{~km}$ long and follows a northeasterly flow path running from $24^{\circ} \mathrm{N}, 26^{\circ} \mathrm{E}$ to $26^{\circ} \mathrm{N}, 28^{\circ} \mathrm{E}$, and continuing to $29^{\circ} \mathrm{N}, 29^{\circ} \mathrm{E}$ (Figure 5). Its location was chosen on the basis of the piezometric surface [Ball, 1927] and its proximity to sampled wells in the western Dakhla, Farafra and Bahariya Oases. Although no groundwater samples are located along the first $400 \mathrm{~km}$ of the flow path, it was desirable to include a likely remote recharge area in the model in order to estimate groundwater age. At various locations along the transect the crosssectional widths of each lithologic formation were either directly taken or interpolated from published cross sections based on aeromagnetic interpretation maps, wells, outcrops and cores (Figure 2) [Research Institute for Groundwater, 1988; Thorweihe, 1990]. Water-bearing limestone deposits were ignored, since they are not hydraulically connected to the Nubian sandstone. 


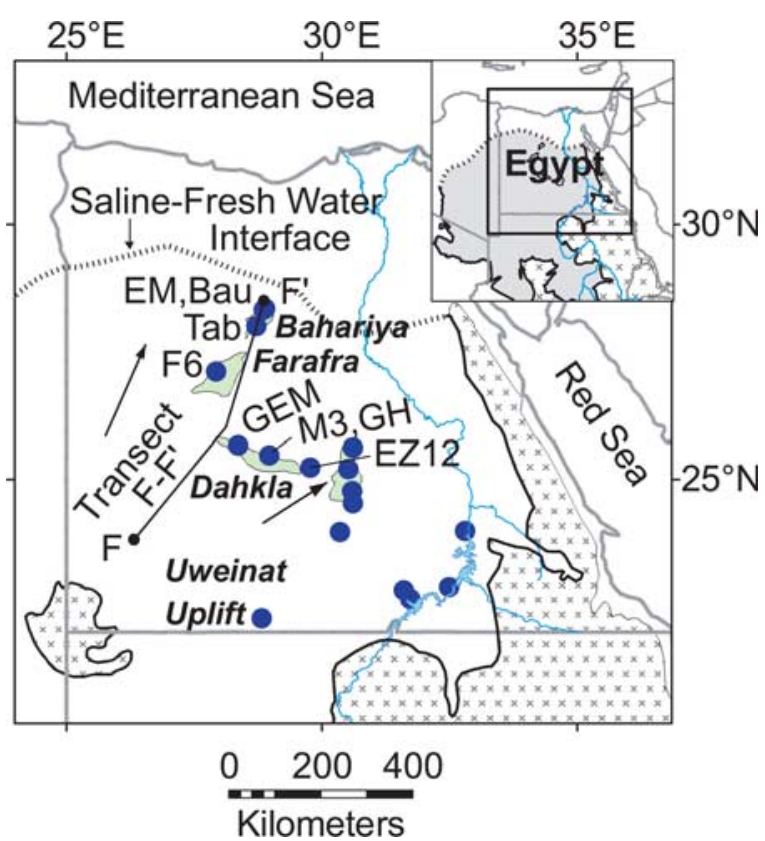

Figure 5. Modeled transect F-F' and groundwater flow directions (arrows) in the Nubian Aquifer.

[20] The modeled flow regime includes advection, dispersion and diffusion. The present arid conditions of the Western Desert ensure minimal surface recharge of the Nubian Aquifer; this was simulated by capping the transect with a $10 \mathrm{~cm}$ layer of extremely low permeability. Recharge enters the transect as baseflow through the left boundary, while discharge occurs at the surface and as horizontal flow through the right boundary. The basement is sealed with respect to groundwater and solute flow. Table 3 lists the boundary conditions affecting the flow of water and solutes. The basal and surface $\mathrm{Cl}^{-}$concentrations provide best fit of the measured concentrations as well as other published values [Attia, 2001]. The range of ${ }^{36} \mathrm{Cl} / \mathrm{Cl}$ secular equilibrium values for sandstone is generally 5 to $10 \times 10^{-15}$; the minimum value in that range is used as the assumed basal ${ }^{36} \mathrm{Cl} / \mathrm{Cl}$ value due to high sand percentage in the aquifer matrix, while the steady state surface ${ }^{36} \mathrm{Cl} / \mathrm{Cl}$ ratio is $130 \times$ $10^{-15}$.

[21] The stratigraphy of the modeled transect includes the four water-bearing sandstone horizons, the interbedded Abu Ballas shale, and the confining shale (Figure 6). While each sandstone and shale formation contains percentages of these rock types that are in general agreement with published ranges of sand percentage in Attia [2001], modeling the reported values of permeability [Thorweihe,
Table 3. Boundary Conditions and Model Parameters of the Basin2 Model of the Nubian Aquifer

\begin{tabular}{|c|c|}
\hline Parameter & Value $^{a}$ \\
\hline Temperature & vertical \\
\hline Run & steady \\
\hline Porosity calculation & equilibrium \\
\hline $\begin{array}{l}\text { Rock type averaging } \\
\text { in the } \mathrm{x} \text {-direction }\end{array}$ & arithmetic \\
\hline $\begin{array}{l}\text { Rock type averaging } \\
\text { in the } \mathrm{z} \text {-direction }\end{array}$ & harmonic \\
\hline Flow & full \\
\hline Salinity & full \\
\hline Left and right boundaries & open \\
\hline Length of entire transect & $743 \mathrm{~km}$ \\
\hline Number of columns of nodes & 20 \\
\hline $\begin{array}{l}\text { Minimum number } \\
\text { of nodes in a stratum }\end{array}$ & 3 \\
\hline Maximum width of nodal row & $50 \mathrm{~m}$ \\
\hline Surface temperature & $26^{\circ} \mathrm{C}$ \\
\hline Heat flow & $0.4 \mathrm{HFU}$ \\
\hline $\begin{array}{l}\text { Elevation of water table } \\
\text { at left-hand boundary }\end{array}$ & $300 \mathrm{~m} \mathrm{ASL}$ \\
\hline Basal $\mathrm{Cl}^{-}$concentration & $8 \mathrm{ppm}$ \\
\hline Surface $\mathrm{Cl}^{-}$concentration & $300 \mathrm{ppm}$ \\
\hline Basal ${ }^{36} \mathrm{Cl}$ concentration & $40 \times 10^{-15}$ \\
\hline Surface ${ }^{36} \mathrm{Cl}$ concentration & $240 \times 10^{-13}$ \\
\hline $\begin{array}{l}\text { Diffusion coefficient of } \mathrm{Cl}^{-}, \\
\text {sandstone and shale }\end{array}$ & $10^{-6} \mathrm{~cm}^{2} / \mathrm{sec}^{*}$ \\
\hline Maximum permeability of sandstone & 4 darcy \\
\hline Maximum permeability of shale & 0.01 darcy \\
\hline Anisotropy of sandstone & 4.8 \\
\hline Anisotropy of shale & 20 \\
\hline $\begin{array}{l}\text { Reducible porosity } \\
\text { of sandstone }\end{array}$ & 0.10 \\
\hline $\begin{array}{l}\text { Reducible porosity } \\
\text { of shale }\end{array}$ & 0.15 \\
\hline $\begin{array}{l}\text { Irreducible porosity } \\
\text { of sandstone }\end{array}$ & 0.18 \\
\hline $\begin{array}{l}\text { Irreducible porosity } \\
\text { of shale }\end{array}$ & $0.05^{*}$ \\
\hline$[\mathrm{U}]$ content of sandstone & $0.7 \mathrm{ppm}$ \\
\hline [U] content of shale & 3.2 ppm* \\
\hline [Th] content of sandstone & $1.95 \mathrm{ppm}$ \\
\hline [Th] content of shale & 11.7 ppm* \\
\hline [Cl] content of sandstone & $5 \mathrm{ppm}$ \\
\hline [Cl] content of shale & $100 \mathrm{ppm}$ \\
\hline [K] content of sandstone & 10,700 ppm* \\
\hline [K] content of shale & $26,600 \mathrm{ppm}^{*}$ \\
\hline $\begin{array}{l}\text { Fraction sandstone } \\
\text { in confining layer }\end{array}$ & 0.1 \\
\hline $\begin{array}{l}\text { Fraction sandstone } \\
\text { confining layer }\end{array}$ & 0.1 \\
\hline $\begin{array}{l}\text { Fraction sandstone in } \\
\text { Horizon A (Taref Formation) }\end{array}$ & 0.78 \\
\hline $\begin{array}{l}\text { Fraction sandstone in } \\
\text { Horizon B (Sabaya Formation) }\end{array}$ & 0.81 \\
\hline $\begin{array}{l}\text { Fraction sandstone in the } \\
\text { Abu Ballas Formation }\end{array}$ & 0.1 \\
\hline $\begin{array}{l}\text { Fraction sandstone in Horizon C } \\
\quad \text { (Six Hills Formation) }\end{array}$ & 1 \\
\hline $\begin{array}{l}\text { Fraction sandstone in } \\
\text { Horizon D (Paleozoic) }\end{array}$ & 0.9 \\
\hline
\end{tabular}

\footnotetext{
${ }^{\mathrm{a}}$ Asterisk denotes Basin2 default.
} 


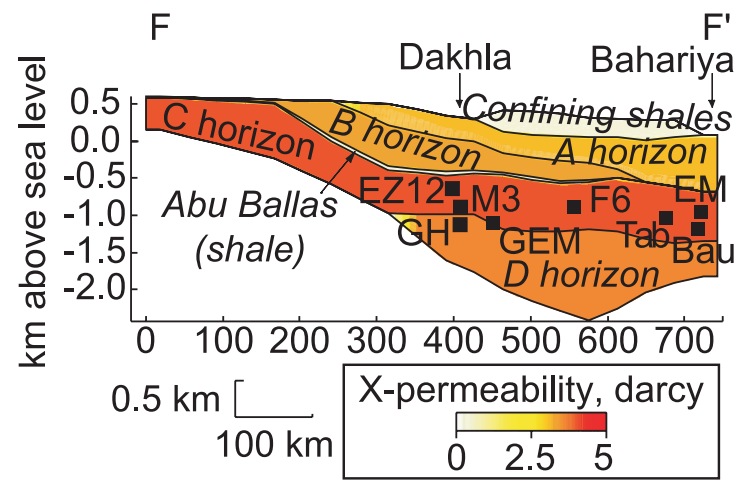

Figure 6. Steady-state Basin2 hydrologic model of transect F-F' showing stratigraphy and horizontal permeability. Squares indicate locations of sampled wells in the western Dakhla, Farafra, and Bahariya Oases. Scale on the bottom left indicates stratigraphic dimensions. The black squares indicate locations of wells in the western Dakhla, Farafra, and Bahariya Oases proximal to the modeled transect.

1990] was paramount in defining each stratum. Basin2 calculates permeability according to its relationship with porosity,

$$
\log k_{x}=A \varphi+B
$$

in which $k_{x}$ is horizontal permeability and $\varphi$ is porosity. The coefficients $A$ and $B$ were determined for sandstone and shale using the published values of hydraulic conductivity and porosity of Brinkmann et al. [1987] and Hesse et al. [1987]. Modeled horizontal permeability ranges between $\sim 3$ and 4 darcy in the sandstone horizons and $\sim 0.5$ darcy in the shales. The predicted average linear velocity, calculated from several properties including porosity, permeabil-

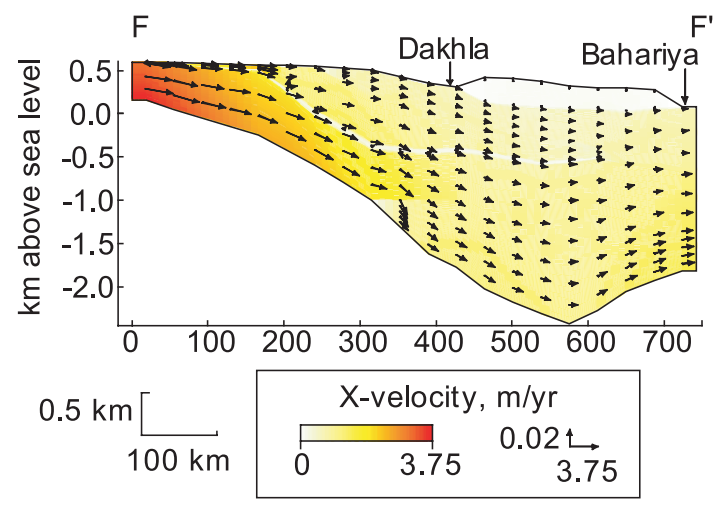

Figure 7. Steady-state Basin2 hydrologic model of transect F-F' showing horizontal groundwater velocities.

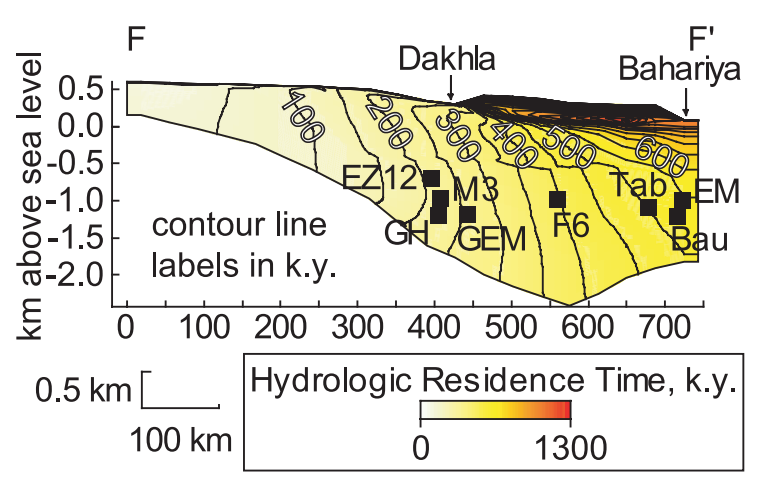

Figure 8. Steady-state Basin2 hydrologic model of transect F-F' showing predicted groundwater ages. The black squares indicate locations of wells in the western Dakhla, Farafra, and Bahariya Oases proximal to the modeled transect.

ity, hydraulic potential, heat flow, fluid density, and the small amount $(<0.1 \mathrm{~mm} / \mathrm{yr})$ of surface recharge, is $\sim 1-3 \mathrm{~m} / \mathrm{yr}$ (Figure 7 ). The velocity and direction of flow are disturbed across the $\mathrm{Abu}$ Ballas formation, which has low permeability, and there are low velocities in the confining shale. Groundwater residence time increases from zero at the left boundary to $\sim 900$ kyr immediately before discharge at the surface of the right boundary, and reaches $1300 \mathrm{kyr}$ in the confining shale (Figure 8).

[22] The vertical $\mathrm{Cl}^{-}$gradient is preserved throughout the flowpath in the predicted distribution of $\mathrm{Cl}^{-}$(Figure 9). Predicted ${ }^{36} \mathrm{Cl} / \mathrm{Cl}$ ratios decay from $\sim 130 \times 10^{-15}$ at the surface of the basin at "recharge" (left boundary of the transect) to $\sim 50 \times 10^{-15}$ at the right boundary (Figure 10). Although the predicted ratios at Bahariya are greater than measured values, ${ }^{36} \mathrm{Cl}$ concentrations are best fit throughout the aquifer in this model (Figure 11). Measured ratios are lower than predicted because the model fails to account for the greater $\mathrm{Cl}^{-}$concentrations at Bahariya.

\subsection{Ages of Groundwater From ${ }^{36} \mathrm{Cl}$ Data 4.3.1. Using ${ }^{36} \mathrm{Cl}$ as a Tracer for Isotopic Residence Time}

[23] The radioactive tracer ${ }^{36} \mathrm{Cl}\left(\mathrm{t}_{1 / 2}=301 \pm 2 \mathrm{kyr}\right)$ has been used for dating very old groundwaters since the 1980s. It is produced in the atmosphere by spallation of $\operatorname{Ar}\left({ }^{40} \operatorname{Ar}(p, n \alpha){ }^{36} \mathrm{Cl}\right)$, falls out primarily as wet deposition along with stable $\mathrm{Cl}$ from marine aerosols, and after concentration by 


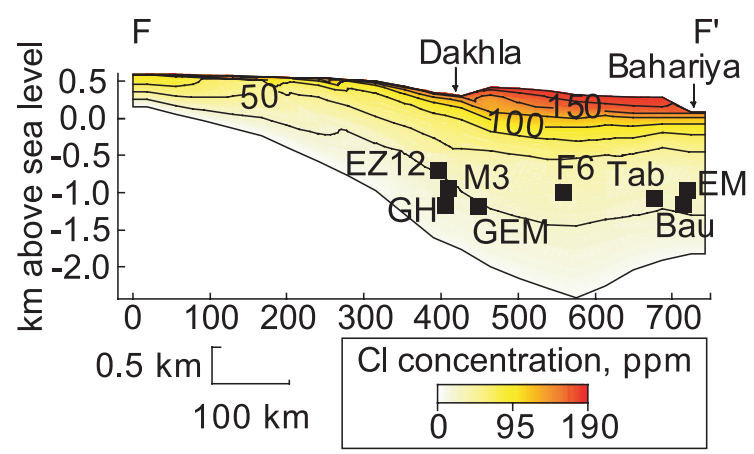

Figure 9. Steady-state Basin2 hydrologic model of transect F-F' showing predicted $\mathrm{Cl}^{-}$distribution with advection, diffusion, and dispersion. The black squares indicate locations of wells in the western Dakhla, Farafra, and Bahariya Oases proximal to the modeled transect.

evapotranspiration, enters the groundwater system. $\mathrm{Cl}$ is considered a conservative groundwater tracer and groundwater age can be calculated from the decay of the atmospheric ${ }^{36} \mathrm{Cl}$; however, in practice several factors complicate its use. The initial ratio of ${ }^{36} \mathrm{Cl} / \mathrm{Cl}$ in recharge waters varies with latitude [Lal and Peters, 1967], meteorological conditions [Keywood et al., 1998], distance between the recharge area and marine coastline [Fabryka-Martin et al., 1987], and time [Phillips, 2000; Plummer et al., 1997]. Direct measurements of ${ }^{36} \mathrm{Cl}$ in modern local recharge are often used as initial values, but this practice does not address the problem of temporal variation of ${ }^{36} \mathrm{Cl}$ deposition in paleorecharge.

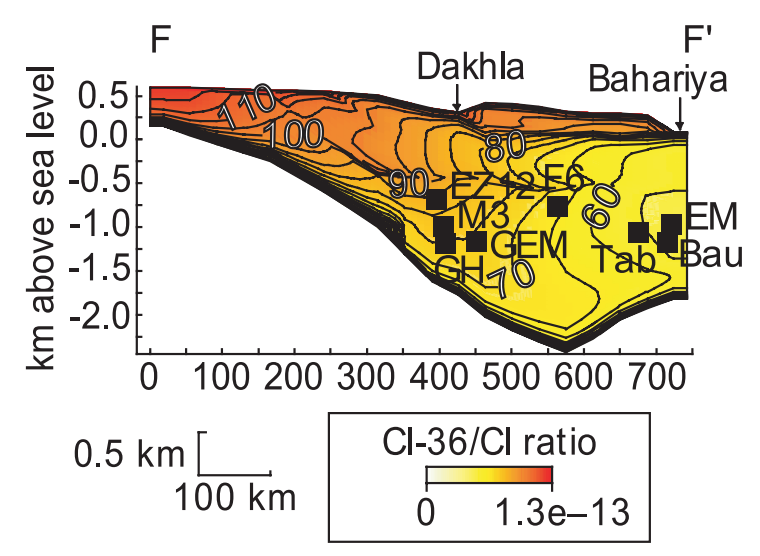

Figure 10. Steady-state Basin2 hydrologic model of transect F-F' showing predicted ${ }^{36} \mathrm{Cl} / \mathrm{Cl}$ distribution. The black squares indicate locations of wells in the western Dakhla, Farafra, and Bahariya Oases proximal to the modeled transect.

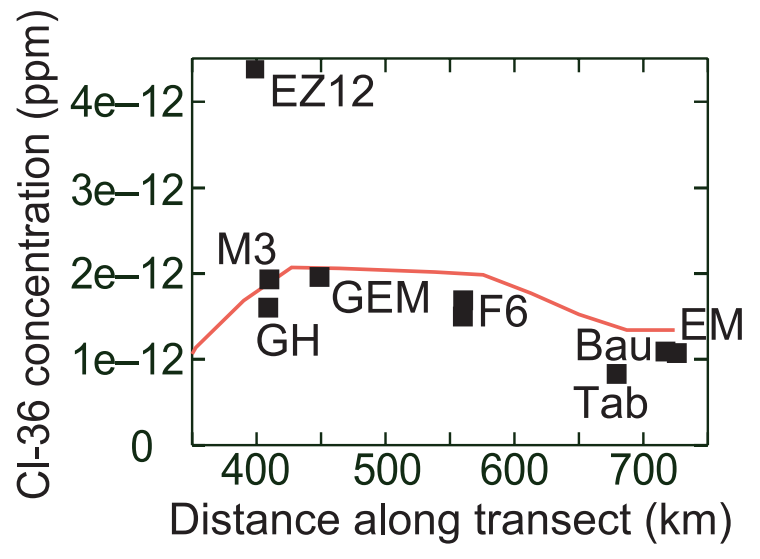

Figure 11. Predicted ${ }^{36} \mathrm{Cl}$ concentration at the lower $\mathrm{C}$ and upper D horizons in the steady-state Basin 2 model. The black squares indicate locations of wells in the western Dakhla, Farafra, and Bahariya Oases proximal to the modeled transect.

[24] Another complication arises from the in situ production and behavior of ${ }^{36} \mathrm{Cl}$. For water containing as little as $75-150 \mathrm{ppm} \mathrm{Cl}^{-}$there may be sufficient subsurface ${ }^{36} \mathrm{Cl}$ production from the neutron flux caused by the decay of $\mathrm{U}$ and $\mathrm{Th}$ series elements in the rock matrix to invalidate the method [Park et al., 2002]. The mixing of two endmembers (young, ${ }^{36} \mathrm{Cl}^{-}$enriched water and old, ${ }^{36} \mathrm{Cl}^{-}$depleted water) can cause an apparent decrease in ${ }^{36} \mathrm{Cl} / \mathrm{Cl}$ ratios that might otherwise be attributed to simple decay [Fontes and Andrews, 1994; Park et al., 2002]. Furthermore, mass transport across formations with higher equilibrium ${ }^{36} \mathrm{Cl} / \mathrm{Cl}$ ratios, higher salinities, or higher concentrations of $U$ and Th can cause increases in aquifer ${ }^{36} \mathrm{Cl}$ concentrations. The lack of comparable modern recharge, the uncertainties in climate, extent, location and time of paleorecharge, the effects of aridity, the partial confinement of the aquifer, and the effects of cross-formational flow are potential complicating factors in using ${ }^{36} \mathrm{Cl}$ to date Nubian Aquifer groundwaters.

\subsubsection{Equations Relating ${ }^{36} \mathrm{Cl}$ and Groundwater Age}

[25] In the absence of subsurface addition of stable $\mathrm{Cl}$ or nucleogenic ${ }^{36} \mathrm{Cl},{ }^{36} \mathrm{Cl} / \mathrm{Cl}$ ratios are converted to groundwater age by the radioactive decay of the initial ${ }^{36} \mathrm{Cl} / \mathrm{Cl}$ ratio:

$$
t=-\frac{1}{\lambda} \ln \left(\frac{R_{m}}{R_{i}}\right)
$$

where $R_{m}$ and $R_{i}$ are the measured and initial ${ }^{36} \mathrm{Cl} /$ $\mathrm{Cl}$ ratios, respectively; $\lambda$ is the decay constant of 


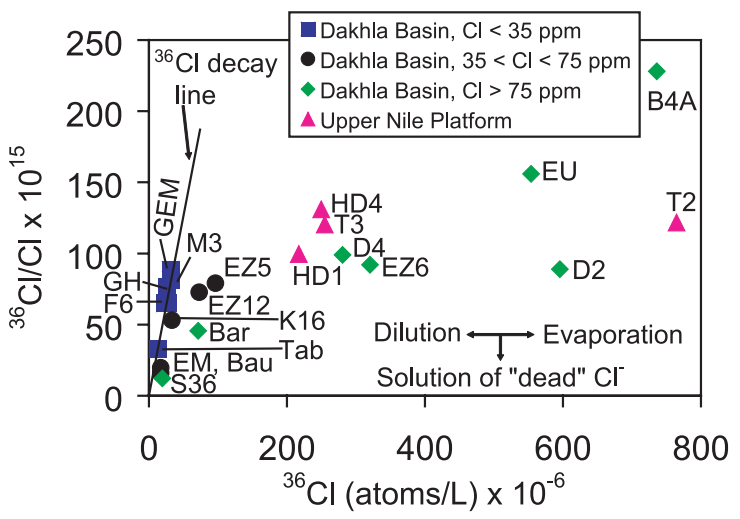

Figure 12. Values of ${ }^{36} \mathrm{Cl} / \mathrm{Cl}$ versus ${ }^{36} \mathrm{Cl} / \mathrm{L}$ for Nubian Aquifer samples. Note that samples are grouped by $\mathrm{Cl}^{-}$ concentration.

${ }^{36} \mathrm{Cl},\left(2.303 \times 10^{-6} \mathrm{yr}^{-1}\right)$; and $t$ is the age of the water in years. If the subsurface secular equilibrium ratio $\left(R_{s e}^{S S}\right)$ is taken into account but no additional subsurface $\mathrm{Cl}^{-}$is added, the following equation, rearranged and solved for time, may be used [after Bentley et al., 1986a]:

$$
t=-\frac{1}{\lambda} \ln \frac{R_{m}-R_{s s}^{s e}}{R_{i}-R_{s s}^{s e}}
$$

An $R_{s e}^{s s}$ value of $5 \times 10^{-15}$ has been chosen as a reasonable estimate for the sandstone of the Nubian Aquifer (section 3.2). If a sample contains additional subsurface $\mathrm{Cl}^{-}$but has not been mixed with other waters, and if the additional $\mathrm{Cl}^{-}$is in secular equilibrium $\left(\mathrm{R}_{\mathrm{rk}}\right)$ with some rock deposit or stratum that either may or may not have the same $R_{s e}$ as the aquifer itself, a mass balance approach may be taken:

$$
R_{m} C_{m}=\left[\left(R_{i}-R_{s s}^{s e}\right) e^{-\lambda t}+R_{s s}^{s e}\right] \times C_{i}+R_{r k}^{s e} C_{u n} .
$$

This equation can be rearranged to solve for time:

$$
t=-\frac{1}{\lambda_{36}} \ln \left[\frac{1}{R_{i}-R_{s s}^{s e}} \times\left(\frac{\left(R_{m} C_{m}-R_{r k}^{s e} C_{r k}\right)}{C_{i}}-R_{s s}^{s e}\right)\right] .
$$

\subsubsection{Groundwater Ages Along the Modeled Transect}

[26] Ratios of ${ }^{36} \mathrm{Cl} / \mathrm{Cl}$ in the Dakhla Basin range over an order of magnitude from $12.2 \times 10^{-15}$ to $228 \times 10^{-15}$. Lower ratios are generally found to the north and east while higher ratios are found at the most upgradient wells at the Dakhla Oasis and at East Uweinat. However, shallow wells also generally have higher ratios. Ratios of ${ }^{36} \mathrm{Cl} / \mathrm{Cl}$ vary less in the Upper Nile Platform, ranging from 100 to $131 \times 10^{-15}$, with larger ratios to the southeast. [27] Measured ${ }^{36} \mathrm{Cl} / \mathrm{Cl}$ ratios versus ${ }^{36} \mathrm{Cl}$ concentrations are shown in Figure 12. If certain assumptions are valid, then ${ }^{36} \mathrm{Cl}$ decay is represented by a line extending from the recharge water to the origin. These assumptions include (1) constant $\mathrm{Cl}$ concentration and (2) piston flow. This model describes water in "packets" that move in onedimensional "flow tubes" and do not mix with other packets, so mass transport is accomplished solely by advection. In reality ${ }^{36} \mathrm{Cl}$ concentrations and ${ }^{36} \mathrm{Cl} / \mathrm{Cl}$ ratios can change by groundwater mixing, diffusion, dispersion, and complex processes such as ion filtration.

[28] In the Nubian Aquifer, samples from the D or $\mathrm{C} / \mathrm{D}$ horizons with consistently low salinity $\left(<35 \mathrm{mg} / \mathrm{L} \mathrm{Cl}^{-}\right)$show little scatter along a decay line constrained to go through the origin $\left(\mathrm{R}^{2}=\right.$ 0.936; Figure 12). With no subsurface addition of either $\mathrm{Cl}^{-}$or ${ }^{36} \mathrm{Cl}$, residence time relative to the Dakhla Oasis can be easily assigned using measured ${ }^{36} \mathrm{Cl} / \mathrm{Cl}$ ratios and assuming $R_{\text {se }}^{s s}$ is $5 \times 10^{-15}$ (equation (2)). Using the average ${ }^{36} \mathrm{Cl} / \mathrm{Cl}$ ratio in the low- $\mathrm{Cl}^{-}$Dakhla samples $\left(82.1 \times 10^{-15}\right)$ as $\mathrm{R}_{i}$, groundwater age increases $110 \mathrm{kyr}$ to $\mathrm{F} 6$ and $440 \mathrm{kyr}$ to Tab in southern Bahariya. These relative isotopic residence times exceed the relative hydrologic residence times calculated by Basin 2 by $32-$ $76 \%$ (Table 4) but indicate lateral flow in the expected northeasterly direction.

[29] Samples with slightly higher salinities (33 to $70 \mathrm{mg} / \mathrm{L} \mathrm{Cl}^{-}$) plot to the right of the first decay line (Figure 12), and many may be related to the more dilute samples by simple evaporation. All Dakhla samples (GEM, M3, GH, EZ12, EZ5 and EZ6) regardless of depth or concentration have similar ${ }^{36} \mathrm{Cl} / \mathrm{Cl}$ ratios; they may be isochronous, with no addition of $\mathrm{Cl}^{-}$having a different ${ }^{36} \mathrm{Cl} / \mathrm{Cl}$ ratio. The similarity in $\delta^{37} \mathrm{Cl}$ values of the low- $\mathrm{Cl}^{-}$ Dakhla samples and EZ12 is consistent with this explanation. Therefore the shallow Dakhla samples are assigned the same relative residence times as the deep samples. Recharge from the most recent pluvial periods, 25-40 kyr BP and 4.5-9.5 kyr BP, is not detectable in the $\mathrm{B}, \mathrm{C}$ and $\mathrm{D}$ horizons at Dakhla, and flow and discharge of stored, old water from remote areas upgradient is occurring.

[30] The samples from northern Bahariya (EM and $\mathrm{Bau}$ ), with some nonmeteoric $\mathrm{Cl}^{-}$, lie directly downgradient from Table If their $\mathrm{Cl}^{-}$and ${ }^{36} \mathrm{Cl}$ result from a mixture of Tab-type water $\left(\mathrm{Cl}^{-}=\right.$ 
Table 4. Increases in Groundwater Age (kyr) Relative to the Dakhla Oasis ${ }^{\mathrm{a}}$

\begin{tabular}{cccccc}
\hline Assumed $\mathrm{R}_{s e}^{r k}$ & Basin2 & Equation (1) & Equation $(2)$ & Equation $(4) 5 \times 10^{-15}$ & Equation $(4) 10 \times 10^{-15}$ \\
\hline F6 & 160 & $100(+23,-24)$ & $110(+26,-25)$ & - & - \\
Tab & 250 & $400( \pm 30)$ & $440( \pm 30)$ & - & - \\
Bau & 270 & $620(+37,-34)$ & $720(+50,-45)$ & $340(+50,-45)$ & $440(+64,-56)$ \\
EM & 290 & $700(+600,-240)$ & $850(+\infty,-320)$ & $400(+\infty,-320)$ & $500(+\infty,-400)$ \\
\hline
\end{tabular}

${ }^{\text {a }}$ The average ${ }^{36} \mathrm{Cl} / \mathrm{Cl}$ ratio in the dilute $\left(\mathrm{Cl}^{-}<25 \mathrm{ppm}\right)$ Dakhla samples is $82.1 \times 10^{-15}$ and is used as $\mathrm{R}_{i}$. Secular equilibrium ratios of ${ }^{36} \mathrm{Cl} / \mathrm{Cl}$ are assumed to be $5 \times 10^{-15}$ for Nubian sandstone and $10 \times 10^{-15}$ for shale. Errors represent analytical precision of ${ }^{36} \mathrm{Cl}$ measurements. A dash indicates that the equation is not applicable for that sample.

$\left.23 \mathrm{mg} / \mathrm{L},{ }^{36} \mathrm{Cl} / \mathrm{Cl}=33 \times 10^{-15}\right)$, and a subsurface $\mathrm{Cl}^{-}$source, that source has a ${ }^{36} \mathrm{Cl} / \mathrm{Cl}$ ratio in the range $8-18 \times 10^{-15}$. The maximum subsurface end-member is only possible if no Tab-type water is present; in that case the subsurface source is itself identical to the measured EM and Bau ratios. The minimum subsurface end-member is only possible if water flowing from Tab comprises the entire volume of the sample; thus $\mathrm{Cl}^{-}$would be added to the Tab-type water by diffusion or dissolution. If mixing of waters occurs, the ${ }^{36} \mathrm{Cl} / \mathrm{Cl}$ ratio of the subsurface $\mathrm{Cl}^{-}$source would fall within this range. The values used in calculating the minimum possible subsurface ${ }^{36} \mathrm{Cl} / \mathrm{Cl}$ ratio are a conservative underestimate because some decay of ${ }^{36} \mathrm{Cl}$ would be expected along the flowpath from Tab to Bau and EM. Since the nonmeteoric $\mathrm{Cl}$ is either derived from minerals or residual marine fluid from thick shale interbeds (section 3.1), and groundwater velocity is low at and north of Bahariya due to both the increasing thickness of the impermeable layers and the saline interface to the north, secular equilibrium of ${ }^{36} \mathrm{Cl}$ in the shale pore waters is assumed. A typical $\mathrm{R}_{s e}$ for shale is $13 \times 10^{-15}$ [Fabryka-Martin et al., 1987], which falls midway between the possible end-members described above and supports the idea of diffusion or mixing between Tab-type water and shale pore waters. A slightly lower value of $10 \times 10^{-15}$ is used for the shale $\mathrm{R}_{s e}^{r k}$ in the groundwater age calculations (Tables 4 and 5) because (1) U and Th concentrations in the aquifer matrix are expected to be low and (2) mixing of different types of waters is not indicated by stable water isotopes (Table 2). Thus equation (4) is the preferred relationship between age and ${ }^{36} \mathrm{Cl} / \mathrm{Cl}$ ratios for the Bau and EM samples. If ${ }^{36} \mathrm{Cl} / \mathrm{Cl}$ ratios are used without adjustment for subsurface addition of $\mathrm{Cl}^{-}$and ${ }^{36} \mathrm{Cl}$, the increase in residence time from the Dakhla Oasis to Bau is $720 \mathrm{kyr}$ and $850 \mathrm{kyr}$ to EM (equation (2); Table 4). When the addition of shale $\mathrm{Cl}^{-}$is assumed the predicted increases are somewhat lower: $440 \mathrm{kyr}$ for Bau and $500 \mathrm{kyr}$ for EM. Nonetheless, relative residence times predicted by all ${ }^{36} \mathrm{Cl}$ methods along the Dakhla-Bahariya flowpath are greater than those predicted by Basin2.

[31] The Basin 2 model indicates $130 \times 10^{-15}$, the best-fit calculated surface ratio, as a possible $\mathrm{R}_{i}$ value (Figure 8). If this value is used in equations (1), (2), and (4), absolute residence times for all samples along the modeled transect can be calculated. Using the equation preferred for each sample and the $\mathrm{R}_{s e}^{r k}$ assumption as described above, groundwater ages range from $\sim 150 \mathrm{kyr}$ at the Dakhla Oasis to $\sim 700 \mathrm{kyr}$ at Bahariya (Table 5). Where the Basin 2 and ${ }^{36} \mathrm{Cl}$ ages can be compared they generally agree, but the ${ }^{36} \mathrm{Cl}$ age at Farafra is $\sim 20 \%$ less than the Basin2 prediction and the ${ }^{36} \mathrm{Cl}$ ages at Bahariya are $25-30 \%$ greater.

\subsubsection{Groundwater Age at Kharga and the Upper Nile Platform}

[32] The best-fit $\mathrm{R}_{i}$ value of $130 \times 10^{-15}$ may also be used to assign groundwater ages to samples not included in the modeled transect. However, the Kharga/Baris samples show no consistent horizontal salinity pattern; for example the $\mathrm{Cl}^{-}$concentration at $\mathrm{B} 4 \mathrm{~A}$ is three times that of $\mathrm{K} 28$ although they both sample the $\mathrm{A}$ and $\mathrm{B}$ horizons and are only about $18 \mathrm{~km}$ apart (Figure 1). Therefore ${ }^{36} \mathrm{Cl} /$ $\mathrm{Cl}$ ratios may not be interpreted without first determining the suitability of ${ }^{36} \mathrm{Cl}$ dating for each Kharga/Baris sample.

[33] Sample B4A has the highest measured values of ${ }^{36} \mathrm{Cl} / \mathrm{Cl}$ and ${ }^{36} \mathrm{Cl}$ atoms/L (Figure 12). This shallow sample could have been recharged as recently as the Holocene, perhaps with a higher initial ${ }^{36} \mathrm{Cl} / \mathrm{Cl}$ value than the other Nubian Aquifer samples. Alternatively it may have obtained additional $\mathrm{Cl}^{-}$with a high ${ }^{36} \mathrm{Cl} / \mathrm{Cl}$ ratio during infiltration. The Kharga/Baris area has extensive $\left(>150 \mathrm{~km}^{2}\right.$ in area) salt crusts and playas [Hermina, 1990] and secondary cosmic-ray particles can produce ${ }^{36} \mathrm{Cl}$ within a few centimeters of the surface, 
Table 5. Groundwater Ages (kyr) Assuming a Recharge ${ }^{36} \mathrm{Cl} / \mathrm{Cl}$ Ratio of $130 \times 10^{-15 a}$

\begin{tabular}{|c|c|c|c|c|c|}
\hline Assumed $\mathrm{R}_{s e}^{r k}$ & Basin2 & Equation (1) & Equation (2) & Equation (4) $5 \times 10^{-15}$ & Equation (4) $10 \times 10^{-15}$ \\
\hline \multicolumn{6}{|c|}{ Upper Nile Platform } \\
\hline $\mathrm{T} 2$ & - & $30( \pm 20)$ & $29( \pm 20)$ & - & - \\
\hline T3 & - & $30( \pm 20)$ & $35( \pm 20)$ & - & - \\
\hline HD1 & - & $120( \pm 20)$ & $121( \pm 20)$ & - & - \\
\hline HD4 & - & $0(+20)$ & $0(+20)$ & - & - \\
\hline \multicolumn{6}{|c|}{ Dakhla Oasis } \\
\hline EZ5 & - & $220( \pm 30)$ & $230(+40,-30)$ & - & - \\
\hline EZ6 & - & $150( \pm 10)$ & $150( \pm 10)$ & - & - \\
\hline EZ12 & - & $250( \pm 16)$ & $270(+18,-17)$ & - & - \\
\hline GEM & 230 & $200( \pm 17)$ & $210(+19,-18)$ & - & - \\
\hline $\mathrm{GH}$ & 230 & $230(+20,-19)$ & $240(+21,-20)$ & - & - \\
\hline M3 & 230 & $170(+25,-24)$ & $180(+27,-25)$ & - & - \\
\hline \multicolumn{6}{|c|}{ Farafra/Bahariya Oases } \\
\hline F6 & 410 & $300(+24,-23)$ & $320(+26,-25)$ & - & - \\
\hline $\mathrm{Tab}$ & 500 & $600( \pm 30)$ & $650( \pm 30)$ & - & - \\
\hline $\mathrm{Bau}$ & 520 & $820(+37,-340)$ & $930(+50,-45)$ & $550(+50,-45)$ & $650(+64,-56)$ \\
\hline EM & 540 & $900(+600,-240)$ & $1100(+\infty,-320)$ & $600(+\infty,-320)$ & $700(+\infty,-410)$ \\
\hline \multicolumn{6}{|c|}{ Kharga/Baris Oases } \\
\hline Bar & - & $460( \pm 20)$ & $490(+23,-22)$ & - & - \\
\hline K16 & - & $390( \pm 30)$ & $420( \pm 40)$ & - & - \\
\hline D2 & - & $170( \pm 40)$ & $170( \pm 40)$ & - & - \\
\hline D4 & - & $120( \pm 30)$ & $120( \pm 30)$ & - & - \\
\hline $\mathrm{S} 36$ & - & $1000(+240,-150)$ & $1200(+540,-230)$ & $600(+540,-230)$ & $900(+8,-400)$ \\
\hline
\end{tabular}

${ }^{a}$ Secular equilibrium ratios of ${ }^{36} \mathrm{Cl} / \mathrm{Cl}$ are assumed to be $5 \times 10^{-15}$ for Nubian sandstone and $10 \times 10^{-15}$ for shale. Ages calculated by the preferred equation for a sample are in bold. A dash indicates that the method or equation is not applicable for that sample.

causing a ${ }^{36} \mathrm{Cl} / \mathrm{Cl}$ value as high as $10^{-11}$ [Davis et al., 1998a]. Dissolution of such surface salts at Kharga could have increased the ${ }^{36} \mathrm{Cl} / \mathrm{Cl}$ ratio of recharge waters. Whether the high ratio represents recent recharge or dissolved surface halite, the ${ }^{36} \mathrm{Cl}$ ratio of this sample cannot be simply related to the others.

[34] Although K16 taps the $\mathrm{B}$ and $\mathrm{C}$ horizons it is relatively low in $\mathrm{Cl}^{-}$, indicating little addition of $\mathrm{Cl}^{-}$or evaporation. It is appropriate to use equation (2), which calculates a residence time of 420 kyr (Table 5). The $\mathrm{Cl}^{-}$concentrations of Bar and S36 are $\sim 4$ times higher than the deep Dakhla samples, but Bar has no indication of nonmeteoric $\mathrm{Cl}^{-}$from either its $\delta^{37} \mathrm{Cl}$ value or $\mathrm{Br} / \mathrm{Cl}$ ratio. Thus equation (2) calculates a residence time of $490 \mathrm{kyr}$ at Bar (Table 5). However, nonmeteoric $\mathrm{Cl}^{-}$is suggested at $\mathrm{S} 36$ (section 3.1); the ${ }^{36} \mathrm{Cl} / \mathrm{Cl}$ of the added $\mathrm{Cl}$ is unknown, but assuming secular equilibrium with either Nubian sandstone or with typical shale would yield ages of 600 and $900 \mathrm{kyr}$, respectively (equation (4)). With no evidence for either a shale-type secular equilibrium ratio or the low groundwater velocity required for an age of $900 \mathrm{kyr}$, the younger age is preferred (Table 5). The hydrologic and ${ }^{36} \mathrm{Cl}$ isotopic groundwater ages in all Dakhla Basin samples are shown in Figure 13; age increases eastward to Kharga/Baris and northward to Farafra and Bahariya.

[35] The Upper Nile Platform samples may have been affected by varying amounts of evapotranspiration (Figure 12); since ${ }^{36} \mathrm{Cl} / \mathrm{Cl}$ ratios are unaffected by this process and the shallow depths of these wells accounts for their relatively high $\mathrm{Cl}^{-}$ concentrations, equation (2) may be used to estimate groundwater ages. These ages, $\leq 121 \mathrm{kyr}$, are younger than those in the Dakhla Basin and increase northward (Table 5, Figure 13). The relatively high $\mathrm{Cl}^{-}$concentrations may indicate that recharge of these waters occurred under conditions that were relatively dry compared with waters recharged before $\sim 170 \mathrm{kyr}$, but that initial ${ }^{36} \mathrm{Cl} / \mathrm{Cl}$ ratios may not have changed significantly.

\subsection{Ages of Groundwater From ${ }^{4} \mathrm{He}$ Data \\ 4.4.1. Using ${ }^{4} \mathrm{He}$ and ${ }^{40} \mathrm{Ar}$ as Tracers for Isotopic Residence Time}

[36] Recharge water entering the aquifer contains initial concentrations of ${ }^{4} \mathrm{He}$ and ${ }^{40} \mathrm{Ar}$, and may gain additional radiogenic ${ }^{4} \mathrm{He}$ and ${ }^{40} \mathrm{Ar}$ along the 


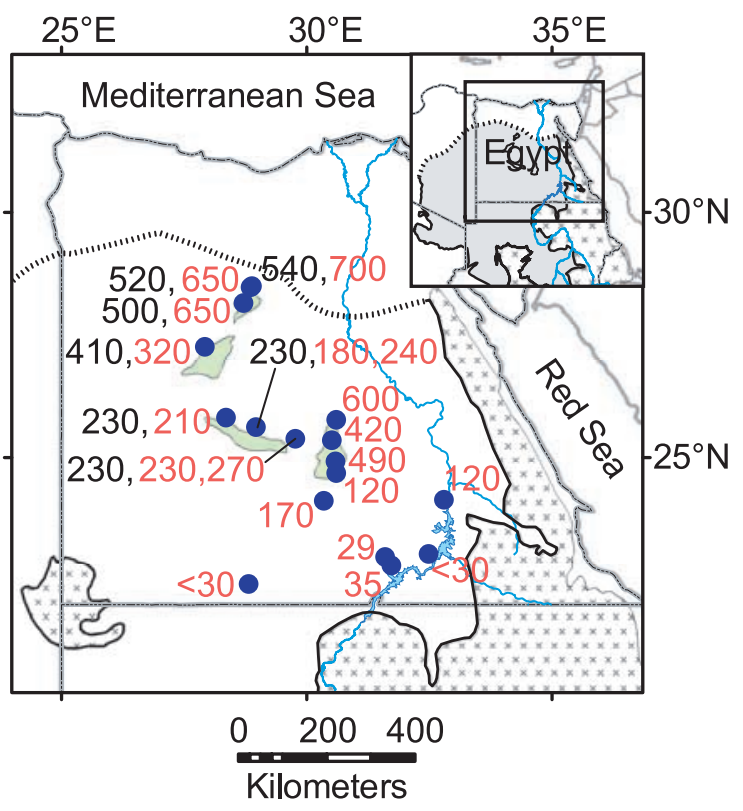

Figure 13. Map of the Western Desert showing hydrodynamic ages (black numbers) and ${ }^{36} \mathrm{Cl}$ ages (red numbers) calculated from ${ }^{36} \mathrm{Cl} / \mathrm{Cl}$ ratios and assuming $R i=130 \times 10^{-15}$, Rse ss $=5 \times 10^{-15}$, and Rse $r k=\times 10^{-15}$ (Table 6).

flowpath. ${ }^{4} \mathrm{He}$ has been used to understand groundwater behavior in several regions, including the Paris Basin [Castro et al., 1998a, 1998b; Marty et al., 1993] and the Great Artesian Basin [Torgersen and Clarke, 1987; Bethke et al., 1999]. ${ }^{4} \mathrm{He}$ is a particularly suitable proxy for groundwater age because, like age, it accumulates over time, and has little interaction with the aquifer matrix [Bethke and Johnson, 2002]. ${ }^{40} \mathrm{Ar}$ also accumulates over time, but is produced at a slower rate than ${ }^{4} \mathrm{He}$ in most aquifers. High groundwater residence times are indicated by ${ }^{4} \mathrm{He}$ concentrations that are orders of magnitude greater than initial concentrations and by ${ }^{40} \mathrm{Ar} /{ }^{36} \mathrm{Ar}$ ratios greater than the atmospheric ratio (296).

[37] In practice three major sources of dissolved $\mathrm{He}$ and $\mathrm{Ar}$ should be evaluated: the initial component from the atmosphere, the in situ component produced within the aquifer rock matrix, and the external flux from the mantle and underlying crust (usually negligible for ${ }^{40} \mathrm{Ar}$ [Lehmann et al., 1993; Ballentine et al., 1994]). The atmospheric component consists of the amount of the gas dissolved according to its solubility equilibrium as well as the amount entrained as excess air. Although the solubility equilibria for gases are well known from labora- tory experiments [e.g., Weiss, 1971], the phenomenon of "excess air", or air that is entrained in recharge waters in excess of solubility equilibria, is frequently observed but incompletely understood; for a detailed review, see Stute and Schlosser [2000] and Holocher et al. [2002].

[38] In situ ${ }^{4} \mathrm{He}$ and ${ }^{40} \mathrm{Ar}$ may accumulate where concentrations of parent nuclides $\left({ }^{235,238} \mathrm{U}\right.$ and ${ }^{232} \mathrm{Th}$ for ${ }^{4} \mathrm{He} ;{ }^{40} \mathrm{~K}$ for ${ }^{40} \mathrm{Ar}$ ) in the rock matrix are high and the velocity of the groundwater is low [Tolstikhin et al., 1996]. From the concentrations of the parent nuclides in the rock, a production rate of each radiogenic isotope can be calculated, providing the relationship of age to isotope concentration.

[39] The external component of dissolved He may be from degassing of the underlying crust or mantle, or from adjacent aquitard formations. Crustal and mantle He can be distinguished from each other because the mantle contains primordial ${ }^{3} \mathrm{He}$ and thus has a characteristic ${ }^{3} \mathrm{He} /{ }^{4} \mathrm{He}$ ratio much higher than the crustal ratio. However, the external flux of ${ }^{4} \mathrm{He}$ into groundwaters is difficult to quantify; if ignored, unreasonably long residence times will be determined. Studies have indicated that crustal degassing of ${ }^{4} \mathrm{He}$ is constant only on a regional scale [Torgersen and Clarke, 1987; Castro et al., 2000]. The uncertainty and the spatial variation of the external flux of $\mathrm{He}$ into groundwaters is the major obstacle to devel-

Table 6. Concentrations of Radiogenic He and Ar, and ${ }^{3} \mathrm{He} /{ }^{4} \mathrm{He}$ Isotope Ratios in Nubian Aquifer Groundwaters and in Air-Saturated Water at $20^{\circ} \mathrm{C}^{\mathrm{a}}$

\begin{tabular}{|c|c|c|c|}
\hline Well & $\begin{array}{c}{\left[{ }^{4} \mathrm{He}_{m}\right]} \\
\times 10^{-6} \mathrm{cc} \mathrm{STP} / \mathrm{g}\end{array}$ & $\begin{array}{l}{ }^{3} \mathrm{He}_{m} /{ }^{4} \mathrm{He}_{m} \\
\quad \times 10^{-8}\end{array}$ & $\begin{array}{c}\left.{ }^{[40} \mathrm{Ar}_{m}\right] \\
\times 10^{-5} \mathrm{cc} \mathrm{STP} / \mathrm{g}\end{array}$ \\
\hline \multicolumn{4}{|c|}{ Dakhla Oasis } \\
\hline EZ12 & $3.3( \pm 0.3)$ & $21( \pm 5)$ & $33( \pm 3)$ \\
\hline $\mathrm{GH}$ & $3.0( \pm 0.3)$ & $19( \pm 1)$ & $57( \pm 6)$ \\
\hline \multicolumn{4}{|c|}{ Farafra Oasis } \\
\hline F6 & $3.7( \pm 0.4)$ & $13( \pm 1)$ & $50( \pm 5)$ \\
\hline \multicolumn{4}{|c|}{ Bahariya Oasis } \\
\hline Bau & $5.1( \pm 0.5)$ & $11( \pm 1)$ & $40( \pm 4)$ \\
\hline \multicolumn{4}{|c|}{ Kharga/Baris Oases } \\
\hline S36 & $43( \pm 4)$ & $9( \pm 1)$ & $67( \pm 7)$ \\
\hline Bar & $32( \pm 3)$ & $20( \pm 2)$ & $50( \pm 5)$ \\
\hline
\end{tabular}

ASW Equilibrium Concentrations, 600 masl, $0.3 \mathrm{ppm} \mathrm{Cl}^{-}$ 0.041

29

\footnotetext{
${ }^{\mathrm{a}} \mathrm{ASW}$, air-saturated water.
} 
Table 7. Excess and Terrigenic ${ }^{4} \mathrm{He}$ Concentrations and Estimated ${ }^{4} \mathrm{He}$ Groundwater Ages

\begin{tabular}{|c|c|c|c|c|}
\hline Well & $\begin{array}{c}{\left[\mathrm{Ne}_{e x}\right]} \\
\times 10^{-7} \mathrm{cc} \mathrm{STP} / \mathrm{g}\end{array}$ & $\begin{array}{c}{\left[{ }^{4} \mathrm{He}_{e x}\right]} \\
\times 10^{-7} \mathrm{cc} \mathrm{STP} / \mathrm{g}\end{array}$ & $\begin{array}{c}{\left[{ }^{4} \mathrm{He}_{\text {ter }}\right]} \\
\times 10^{-7} \mathrm{cc} \mathrm{STP} / \mathrm{g}\end{array}$ & $\begin{array}{c}{ }^{4} \mathrm{He} \text { Residence Time, } \\
\text { kyr }\end{array}$ \\
\hline \multicolumn{5}{|c|}{ Dakhla Oasis } \\
\hline EZ12 & 1.4 & 0.349 & 30.9 & 940 \\
\hline $\mathrm{GH}$ & 4.4 & 1.13 & 28.6 & 870 \\
\hline \multicolumn{5}{|c|}{ Farafra Oasis } \\
\hline F6 & 4.1 & 1.04 & 35.6 & 1100 \\
\hline \multicolumn{5}{|c|}{ Bahariya Oasis } \\
\hline Bau & 2.4 & 0.615 & 49.6 & 1500 \\
\hline \multicolumn{5}{|c|}{ Kharga/Baris Oases } \\
\hline S36 & 7.7 & $1.96^{\circ}$ & 429 & - \\
\hline Bar & 3.2 & 0.814 & 318 & - \\
\hline
\end{tabular}

oping ${ }^{4} \mathrm{He}$ as a quantitative method of determining residence time [Solomon, 2000; Kipfer et al., 2002].

\subsubsection{Equations Relating ${ }^{4} \mathrm{He}$ and Groundwater Age}

[40] The following equations are used to determine the contributions from various sources of ${ }^{4} \mathrm{He}$ [after Kipfer et al., 2002]:

$$
\begin{gathered}
{ }^{4} \mathrm{He}_{m}={ }^{4} \mathrm{He}_{e q}+{ }^{4} \mathrm{He}_{e x}+{ }^{4} \mathrm{He} e_{\text {ter }}, \\
{ }^{4 H e_{e x}}=N e_{e x} \times L_{e x} .
\end{gathered}
$$

The subscripts denote the concentrations measured $(m)$, dissolved according to the solubility equilibrium (eq), dissolved as excess air (ex), and accumulated from in situ production and external flux (ter). Equilibrium concentrations of dissolved gases were calculated assuming recharge salinity of $3 \mathrm{ppm}$, elevation of $600 \mathrm{masl}$, and temperature of $20^{\circ} \mathrm{C} . \mathrm{Ne}_{e x}$ is the difference between the measured concentration of dissolved $\mathrm{Ne}$ and the equilibrium concentration at recharge. $L_{e x}$ is the $\mathrm{He}_{e x} / \mathrm{Ne}_{e x}$ ratio and has a value between 0.22 and 0.288 . Using these values as upper and lower limits changes the calculated ${ }^{4} \mathrm{He}_{\text {ter }}$ by $\sim 1 \%$, so assuming an average value of 0.254 is not a significant source of error.

[41] If it is assumed that external flux of ${ }^{4} \mathrm{He}$ is absent, groundwater ages can be assigned according to [Kipfer et al., 2002]

$$
t=\frac{{ }^{4} H e_{t e r}}{J_{H e}} .
$$

$\mathrm{J}_{H e}$, the accumulation rate, is expressed in cc STP $\mathrm{g}^{-1} \mathrm{yr}^{-1}$ and calculated according to [Kipfer et al., 2002]

$$
J_{H e}=\Lambda_{H e} \frac{\rho_{r}}{\rho_{w}}\left(C_{U} * P_{U}+C_{T h} * P_{T h}\right) *\left(\frac{1-\Theta}{\Theta}\right) .
$$

Three factors have been assumed: $\Lambda_{H e}$, the release factor of ${ }^{4} \mathrm{He}$, equals unity if all ${ }^{4} \mathrm{He}$ produced in the minerals is released into the groundwater; $\rho_{w}$, the density of water, equals $1 \mathrm{~g} / \mathrm{cm}^{3}$; and $\rho_{r}$, the density of the aquifer matrix, equals the average density of sandstone, $2.65 \mathrm{~g} / \mathrm{cm}^{3}$. $\Theta$ is the porosity of the aquifer, which is reported to be $0.15-0.2$ in the sandstone horizons and $0.005-0.2$ in the confining and interbedded shales [Hesse et al., 1987; Brinkmann et al., 1987]. A previous model used 0.17 as average porosity [Brinkmann et al., 1987], which is consistent with the Basin2 model and is used here. $C_{U}$ and $C_{T h}$, the concentrations of $\mathrm{U}$ and Th in the aquifer matrix, have not been measured. As a reasonable estimate the values that provided the best fit to the measured ${ }^{36} \mathrm{Cl} / \mathrm{Cl}$ data in the Basin2 model are used. These values, $1.2 \mathrm{ppm}$ for $C_{U}$ and $3.9 \mathrm{ppm}$ for $C_{T h}$, are slightly less than sandstone of average composition. $P_{U}$ and $P_{T h}$ are rates of ${ }^{4} \mathrm{He}$ production from the decay of $U$ and $T h$ and equal $1.19 \times 10^{-13} \mathrm{cc} \mathrm{STP} \mu \mathrm{g}_{U}^{-1} \mathrm{yr}^{-1}$ and $2.88 \times 10^{-14} \mathrm{cc}$ STP $\mu \mathrm{g}_{\text {Th }}^{-1} \mathrm{yr}^{-1}$, respectively [Kipfer et al., 2002].

\subsubsection{Groundwater Age and ${ }^{4} \mathrm{He}$}

[42] Table 6 lists the measured ${ }^{4} \mathrm{He}$ and ${ }^{40} \mathrm{Ar}$ concentrations and $\mathrm{He}$ isotopic ratios in the samples. Concentrations of ${ }^{40} \mathrm{Ar}$ range from $33-67 \times$ $10^{-5} \mathrm{ccSTP} / \mathrm{g}$ and indicate excess air incorporation at recharge. Ratios of ${ }^{40} \mathrm{Ar} /{ }^{36} \mathrm{Ar}$ were not measurably different from the atmospheric ratio of $295.5 \pm$ 0.5 [Porcelli et al., 2002] so it appears that ${ }^{40} \mathrm{Ar}$ 
production and accumulation within the aquifer is minimal. However, ${ }^{4} \mathrm{He}$ concentrations $(3.0-43 \times$ $10^{-6} \mathrm{ccSTP} / \mathrm{g}$ ) are two to three orders of magnitude greater than the air-water equilibrium concentration of ${ }^{4} \mathrm{He}$ at $20^{\circ} \mathrm{C}$, indicating subsurface addition of ${ }^{4} \mathrm{He}$ that could be used for estimating groundwater ages. ${ }^{3} \mathrm{He} /{ }^{4} \mathrm{He}$ ratios range from 9 to $21 \times 10^{-8}$. Inserting ${ }^{4} \mathrm{He}_{m}$ values (Table 6) and the calculated $\mathrm{N}_{e x}$ values (Table 7) into equations (5) and (6) yield values of ${ }^{4} \mathrm{He}_{\text {ter }}$ that represent the ${ }^{4} \mathrm{He}$ produced in the aquifer as well as any degassing from the crust and/or mantle into the aquifer (Table 7). These two components cannot be separated with available data, but an external source of ${ }^{4} \mathrm{He}$ is particularly apparent in the Kharga and Baris samples. In this area, the flux of $\mathrm{He}$ into the aquifer is anomalously high and ${ }^{4} \mathrm{He}$ was not used to estimate residence time.

[43] ${ }^{4} \mathrm{He}_{\text {ter }}$ concentrations show linear accumulation along the Dakhla-Bahariya flowpath (Table 7), suggesting qualitatively that groundwater age increases by nearly a factor of two between those two points. The $U$ and Th concentrations of the aquifer needed for equation (8) were calculated using the rock compositions that gave the best fit of the measured ${ }^{36} \mathrm{Cl} / \mathrm{Cl}$ data in the Basin2 model, and by assuming that the aquifer is composed of $80 \%$ sandstone and $20 \%$ shale. Thus $\mathrm{C}_{U}$ and $\mathrm{C}_{T h}$ equal 1.2 and $3.9 \mathrm{ppm}$, respectively, and are very close to sandstone of average composition. $\mathrm{J}_{\mathrm{He}}$ then equals $3.3 \times 10^{-12} \mathrm{cc} \mathrm{STP} \mathrm{g}^{-1} \mathrm{yr}^{-1}$ and the corresponding ${ }^{4} \mathrm{He}$ residence times (assuming zero crustal flux of ${ }^{4} \mathrm{He}$ into the aquifer), 870 to $1500 \mathrm{kyr}$, are listed in Table 7. These ages are two to four times greater than either the hydrologic age or the ${ }^{36} \mathrm{Cl}$ isotopic age, which indicates that the assumption of zero external flux is inaccurate. Thus $50-80 \%$ of the ${ }^{4} \mathrm{He}$ may be from a source external to the aquifer.

\section{Conclusion}

[44] The application of the ${ }^{36} \mathrm{Cl}$ method of dating groundwater to the Nubian Aquifer has been significantly enhanced by consideration of ion concentrations and stable $\mathrm{Cl}$ isotope ratios. The highest $\mathrm{Cl}^{-}$ concentrations are found in the shallow horizons of the aquifer; variations in $\mathrm{Br} / \mathrm{Cl}$ ratios suggest that dissolution of accumulated halite near the ground surface contributes significantly to the $\mathrm{Cl}^{-}$content of shallow samples. Increases in $\mathrm{Cl}^{-}$along the flowpath in the deeper portion of the aquifer are small (less than one order of magnitude) and localized, indicating minimal subsurface addition of $\mathrm{Cl}^{-}$along most of the studied portion of the flow- path. Stable $\mathrm{Cl}$ isotope ratios delineate three endmembers in the groundwaters, but the sources and fractionation processes responsible for the differences in $\delta^{37} \mathrm{Cl}$ values are not completely understood. The paleometeoric $\mathrm{Cl}$ in the Dakhla Basin is slightly depleted in ${ }^{37} \mathrm{Cl}$ relative to seawater, but higher $\delta^{37} \mathrm{Cl}$ values in a few deep wells indicate subsurface addition of $\mathrm{Cl}^{-}$. A rock or saline pore fluid source for this $\mathrm{Cl}^{-}$is supported by the correlation of $\delta^{37} \mathrm{Cl}$ values with either increased thickness of the interbedded shales or increased clay content in the aquifer horizons. Water is depleted of $\mathrm{D}$ and ${ }^{18} \mathrm{O}$ and has small variations in $\delta \mathrm{D}$ and $\delta^{18} \mathrm{O}$, however, indicating complete flushing of connate water.

[45] The ${ }^{36} \mathrm{Cl} / \mathrm{Cl}$ ratios in samples from the $\mathrm{C}$ and $\mathrm{D}$ horizons decrease from $89 \times 10^{-15}$ to $12 \times 10^{-15}$ along the flowpath. This establishes the predominance of long, deep flowpaths originating in the southern highlands where paleorecharge was likely to have occurred. Late Quaternary recharge that may have occurred more widely across the Western Desert appears to affect the shallow aquifer horizons only. Ratios of ${ }^{36} \mathrm{Cl} / \mathrm{Cl}$ indicate that groundwater age increases by $\sim 500 \mathrm{kyr}$ from the Dakhla oasis to the northern Bahariya oasis. The ${ }^{36} \mathrm{Cl}$ results yield groundwater age estimates that are in generally good agreement with ${ }^{81} \mathrm{Kr}$ measurements obtained by atom-trap trace analysis [Du et al., 2003; Sturchio et al., 2004].

[46] A two-dimensional numerical hydrodynamic model through the Dakhla Basin estimates groundwater velocity at between 0.5 and $3.5 \mathrm{~m} \mathrm{yr}^{-1}$ and groundwater ages from zero to $900 \mathrm{kyr}$; residence times up to 1.3 m.y. are predicted in the confining shale. By fitting known characteristics of the Dakhla Basin, the model provides an estimate of the initial ${ }^{36} \mathrm{Cl} / \mathrm{Cl}$ ratio of $130 \times 10^{-15}$. Although estimating $\mathrm{R}_{i}$ could lead to large error, residence times from 150 to $700 \mathrm{kyr}$ are the best estimates that can be made with the present data for the Dakhla Basin. These ages are older, and the groundwater velocities slower, than those determined through hydrodynamic calculations by others and by the Basin2 model. If the ${ }^{36} \mathrm{Cl}$ ages are accurate, then pluvial periods during which the Nubian Aquifer was recharged occurred at least intermittently for the past 700,000 years.

[47] Although there are several unknowns in calculating ${ }^{36} \mathrm{Cl}$ groundwater ages in the Nubian Aquifer (initial ${ }^{36} \mathrm{Cl} / \mathrm{Cl}$ ratio, $\mathrm{Cl}^{-}$content of recharging waters, extent of the recharge area, and subsurface ${ }^{36} \mathrm{Cl}$ production), the method has been applied to all but the most concentrated, 
shallow wells by making informed assumptions. $\mathrm{Br} / \mathrm{Cl}$ ratios and stable $\mathrm{Cl}$ isotope ratios are crucial for proper interpretation of ${ }^{36} \mathrm{Cl}$ residence times, as they can indicate addition of $\mathrm{Cl}^{-}$, either from dissolution of surface halite or from subsurface minerals or pore waters. Reasonable values have been assumed for subsurface and initial ${ }^{36} \mathrm{Cl} / \mathrm{Cl}$ ratios, addition of $\mathrm{Cl}^{-}$along the flowpath is minimal, and $\mathrm{Cl}^{-}$concentrations are low in comparison to other large aquifers such as the Great Artesian Basin, Australia, and the Milk River Aquifer, Canada. Chlorine-36 groundwater dating is thus a robust method for the Nubian Aquifer.

[48] Radiogenic accumulation of ${ }^{4} \mathrm{He}$ confirms the age progression indicated by the ${ }^{36} \mathrm{Cl} / \mathrm{Cl}$ ratios, but the flux of external ${ }^{4} \mathrm{He}$ from the underlying crust has not been quantified and is apparently not constant throughout the aquifer. ${ }^{4} \mathrm{He}$ groundwater ages, calculated assuming average concentrations of $U$ and $T h$ in the aquifer matrix as predicted by Basin2, are between two and four times greater than either the hydrodynamic ages predicted by Basin 2 or the ${ }^{36} \mathrm{Cl}$ ages. This discrepancy suggests that either $\mathrm{U}$ and $\mathrm{Th}$ concentrations are underestimated or significant crustal ${ }^{4} \mathrm{He}$ flux occurs. If external He flux and in situ ${ }^{4} \mathrm{He}$ production were better constrained, ${ }^{4} \mathrm{He}$ accumulation could provide a semi-quantitative method for groundwater dating in the Nubian Aquifer.

\section{Acknowledgments}

[49] This work was supported mainly by the U.S. National Science Foundation (grant EAR-0126297). Partial support was provided by the Director, Office of Science, Basic Energy Sciences, Chemical Sciences, Geosciences and Biosciences Division of the U.S. Department of Energy (contract DeAC03-76SF00098) and by NASA's Land-Cover Land-Use Changes program (grant NAG5-12409). We thank two anonymous reviewers for constructive critiques of an earlier version of the manuscript.

\section{References}

Attia, S. Y. G. (2001), Hydrogeological characteristics of the Nubia Sandstone Aquifer system in Dakhla Depression, Western Desert, Egypt, M.Sc., Ain Shams Univ., Cairo, Egypt.

Ball, J. (1927), Problems of the Libyan Desert, Geogr. J., 70, 21-38, 105-128, 209-224.

Ballentine, C. J., M. Mazurek, and A. Gautschi (1994), Thermal constraints on crustal rare gas release and migration: Evidence from Alpine fluid inclusions, Geochim. Cosmochim. Acta, 58, 4333-4348.

Bentley, H. W., F. M. Phillips, and S. N. Davis (1986a), Chlorine 36 in the terrestrial environment, Handb. Environ. Isotope Geochem., 2, 422-475.
Bentley, H. W., F. M. Phillips, S. N. Davis, M. A. Habermehl, P. L. Airey, G. E. Calf, D. Elmore, H. E. Gove, and T. Torgersen (1986b), Chlorine 36 dating of very old groundwater: 1. The Great Artesian Basin, Australia, Water Resour. Res., 22, 1991-2001.

Bethke, C. M., and T. M. Johnson (2002), Paradox of groundwater age, Geology, 30, 107-110.

Bethke, C. M., X. Zhao, and T. Torgersen (1999), Groundwater flow and the ${ }^{4} \mathrm{He}$ distribution in the Great Artesian Basin of Australia, J. Geophys. Res., 104, 12,999-13,011.

Bethke, C. M., M.-K. Lee, and J. Park (2002), Basin Modeling with Basin 2, Release 5.0, Board of Trustees of the Univ. of Ill., Urbana. (Available at http://www.geology.uiuc.edu/ $\sim$ bethke/hydro_software.htm)

Brinkmann, P. J., M. Heinl, R. Hollander, and G. Reich (1987), Retrospective simulation of groundwater flow and transport in the Nubian Aquifer system, in Berliner Geowissenschaftlich Abhandlungen, Ser. A, vol. 75.2, edited by E. Klitzsch and E. Schrank, pp. 465-516, Von Dietrich Reimer, Berlin, Germany.

Castro, M. C., A. Jambon, G. de Marsily, and P. Schlosser (1998a), Noble gases as natural tracers of water circulation in the Paris Basin: 1. Measurements and discussion of their origin and mechanisms of vertical transport in the basin, Water Resour. Res., 34, 2443-2466.

Castro, M. C., P. Goblet, E. Ledoux, S. Violette, and G. de Marsily (1998b), Noble gases as natural tracers of water circulation in the Paris Basin: 2. Calibration of a groundwater flow model using noble gas isotope data, Water Resour. Res., 35, 2467-2483.

Castro, M. C., M. Stute, and P. Schlosser (2000), Comparison of ${ }^{4} \mathrm{He}$ ages and ${ }^{14} \mathrm{C}$ ages in simple aquifer systems: Implications for groundwater flow and chronologies, Appl. Geochem., 15, 1137-1167.

Clark, I. D., and P. Fritz (1997), Environmental Isotopes in Hydrogeology, CRC Press, Boca Raton, Fla.

Coleman, M., T. J. Shepherd, J. J. Durham, J. E. Rouse, and G. R. Moore (1982), Reduction of water with zinc for hydrogen isotope analysis, Anal. Chem., 54, 993-995.

Coplen, T. B., J. D. Wildman, and J. Chen (1991), Improvements in the gaseous hydrogen-water equilibration technique for hydrogen isotope ratio analysis, Anal. Chem., 63, 910-912.

Davis, S. N., D. Cecil, M. Zreda, and P. Sharma (1998a), Chlorine-36 and the initial value problem, Hydrogeol. J., $6,104-114$.

Davis, S. N., D. O. Whittemore, and J. Fabryka-Martin (1998b), Uses of chloride/bromide ratios in studies of potable water, Ground Water, 36, 338-350.

Du, X., R. Purtschert, K. Bailey, B. E. Lehmann, R. Lorenzo, Z.-T. Lu, P. Mueller, T. P. O'Connor, N. C. Sturchio, and L. Young (2003), A new method of measuring ${ }^{81} \mathrm{Kr}$ and ${ }^{85} \mathrm{Kr}$ abundances in environmental samples, Geophys. Res. Lett., 30(20), 2068, doi:10.1029/2003GL018293.

Eggenkamp, H. G. M. (1994) $\delta^{37} \mathrm{Cl}$ : The geochemistry of chlorine isotopes, Ph.D. thesis, Fac. Aardwetenschappen, Univ. Utrecht, Utrecht, Netherlands.

Eggenkamp, H. G. M., J. J. Middelburg, and R. Kreulen (1994), Preferential diffusion of ${ }^{35} \mathrm{Cl}$ relative to ${ }^{37} \mathrm{Cl}$ in sediment so Kau Bay, Halmahera, Indonesia, Chem. Geol., 116, 317-325.

Eggenkamp, H. G. M., R. Kreulen, and A. F. Koster van Groos (1995), Chlorine stable isotope fractionation in evaporites, Geochim. Cosmochim. Acta, 59, 5169-5175.

Elmore, D., and F. M. Phillips (1987), Accelerator mass spectrometry for measurement of long-lived radioisotopes, Science, 236, 543-550. 
Epstein, S., and T. Mayeda (1953), Variation of O-18 content of water from natural sources, Geochim. Cosmochim. Acta, 4, 213-224.

Fabryka-Martin, J., S. N. Davis, and D. Elmore (1987), Applications of ${ }^{129} \mathrm{I}$ and ${ }^{36} \mathrm{Cl}$ in hydrology, Nucl. Instrum. Methods Phys. Res., Sect. B, 29, 361-371.

Fontes, J.-C., and J. N. Andrews (1994), Accelerator mass spectrometry in hydrology, Nucl. Instrum. Methods Phys. Res., Sect. B, 92, 367-375.

Frape, S. K., G. Bryant, R. Blomqvist, and T. Ruskeeniemi (1995), Evidence from stable chlorine isotopes for multiple sources of chloride in groundwaters from crystalline shield environments, paper presented at Symposium on Isotopes in Water Resources Management, U. N. Educ., Sci. and Cult. Organ., Vienna, 20-24 March.

Groen, J., J. Velstra, and A. G. C. A. Meesters (2000), Salinization processes in paleowaters in coastal sediments of Suriname: Evidence from $\delta^{37} \mathrm{Cl}$ analysis and diffusion modeling, J. Hydrol., 234, 1-20.

Herczeg, A. L., T. Torgersen, A. R. Chivas, and M. A. Habermehl (1991), Geochemistry of ground waters from the Great Artesian Basin, Australia, J. Hydrol., 126, 225-245.

Hermina, M. (1990), The surroundings of Kharga, Dakhla and Farafra oases, in The Geology of Egypt, edited by R. Said, pp. 259-292, A. A. Balkema, Brookfield, Vt.

Hesse, K. H., A. Hissene, O. Kheir, E. Schnacker, M. Schneider, and U. Thorweihe (1987), Hydrogeological investigations in the Nubian aquifer system, Eastern Sahara, in Berliner Geowissenschaftlich Abhandlungen, Ser. A, vol. 75.2, edited by E. Klitzsch and E. Schrank, pp. 397-464, Von Dietrich Reimer, Berlin, Germany.

Hiyagon, H., and B. M. Kennedy (1992), Noble-gases in $\mathrm{CH}_{4}$-rich gas-fields, Alberta, Canada, Geochim. Cosmochim. Acta, 56, 1569-1589.

Holocher, J., F. Peeters, W. Aeschbach Hertig, M. Hofer, M. Brennwald, W. Kinzelbach, and R. Kipfer (2002), Experimental investigations on the formation of excess air in quasi-saturated porous media, Geochim. Cosmochim. Acta, 66, 4103-4117.

Joseph, A., J. P. Frangi, and J. F. Aranyossy (1992), Isotope characteristics of meteoric water and groundwater in the Sahelo-Sudanese zone, J. Geophys. Res., 97, 7543-7551.

Keywood, M. D., L. K. Fifield, A. R. Chivas, and R. G. Cresswell (1998), Fallout of chlorine 36 to the Earth's surface in the southern hemisphere, J. Geophys. Res., 103(D7), 8281-8286.

Kipfer, R., W. Aeschbach-Hertig, F. Peeters, and M. Stute (2002), Noble gases in lakes and ground waters, in Noble Gases in Geochemistry and Cosmochemistry, edited by D. Porcelli, C. J. Ballentine, and R. Wieler, pp. 615-700, Mineral. Soc. of Am, Washington, D. C.

Lal, D., and B. Peters (1967), Cosmic ray produced radioactivity on the Earth, Handb. Phys., 46, 551-612.

Lehmann, B. E., H. H. Loosli, D. Rauber, N. Thonnard, and R. D. Willis (1991), ${ }^{81} \mathrm{Kr}$ and ${ }^{85} \mathrm{Kr}$ in groundwater, Milk River aquifer, Alberta, Canada, Appl. Geochem., 6, 419-424.

Lehmann, B. E., S. N. Davis, and J. T. Fabryka-Martin (1993), Atmospheric and subsurface sources of stable and radioactive nuclides used for groundwater dating, Water Resour. Res., 29, 2027-2040.

Lehmann, B. E., et al. (2003), A comparison of groundwater dating with $\mathrm{Kr}-81, \mathrm{Cl}-36$ and He-4 in four wells of the Great Artesian Basin, Australia, Earth Planet. Sci. Lett., 211, $237-$ 250.

Marty, B., T. Torgersen, V. Mayneir, R. K. O’Nions, and G. de Marsily (1993), Helium isotope fluxes and groundwater ages in the Dogger Aquifer, Paris Basin, Water Resour. Res., 29, $1025-1035$.

Pachur, H.-J., H.-P. Röper, S. Kröpelin, and M. Goschin (1987), Late Quaternary hydrography of the eastern Sahara, in Berliner Geowissenschaftlich Abhandlungen, Ser. A, vol. 75.2, edited by E. Klitzsch and E. Schrank, pp. 331384, Von Dietrich Reimer, Berlin, Germany.

Park, J., C. M. Bethke, T. Torgersen, and T. M. Johnson (2002), Transport modeling applied to the interpretation of groundwater ${ }^{36} \mathrm{Cl}$ age, Water Resour. Res., 38(5), 1043, doi:10.1029/2001WR000399.

Phillips, F. M. (2000), Chlorine-36, in Environmental Tracers in Subsurface Hydrology, edited by P. G. Cook and A. L. Herczeg, pp. 299-348, Springer, New York.

Phillips, F. M., H. W. Bentley, S. N. Davis, D. Elmore, and G. B. Swanick (1986), Chlorine 36 dating of very old groundwater: 2. Milk River Aquifer, Alberta, Canada, Water Resour. Res., 22, 2003-2016.

Plummer, M. A., F. M. Phillips, J. Fabryka-Martin, H. J. Turin, P. E. Wigand, and P. Sharma (1997), Chlorine-36 in fossil rat urine: An archive of cosmogenic nuclide deposition during the past 40,000 years, Science, 277, 538-541.

Porcelli, D., C. J. Ballentine, and R. Wieler (2002), An overview of noble gas geochemistry and cosmochemistry, in Noble Gases in Geochemistry and Cosmochemistry, edited by D. Porcelli, C. J. Ballentine, and R. Wieler, pp. 1-18, Mineral. Soc. of Am., Washington, D. C.

Research Institute for Groundwater (1988), Hydrogeological map of Egypt, Tech. Note 70, 120-88-04, Minist. of Public Works and Water Resour., Cairo, Egypt.

Shata, A. A. (1982), Hydrogeology of the Great Nubian Sandstone basin, Egypt, Q. J. Eng. Geol., 15, 127-133.

Shehata, M., and F. Al-Ruwaih (1999), Major ions geochemistry and environmental isotope study of the Nubian Aquifer system, Dakhla Oasis, Western Desert, Egypt, Arab. J. Sci. Eng., 24, 43-58.

Sie, P. M. J., and S. K. Frape (2002), Evaluation of the groundwaters from the Stripa mine using stable chlorine isotopes, Chem. Geol., 182, 565-582.

Solomon, K. (2000), ${ }^{4} \mathrm{He}$ in groundwater, in Environmental Tracers in Subsurface Hydrology, edited by P. G. Cook and A. L. Herczeg, pp. 425-439, Springer, New York.

Sonntag, C. (1984), Autochthoneous groundwater in the confined Nubian Sandstone Aquifers, in Berliner Geowissenschaftlich Abhandlungen, Ser. A, vol. 50, edited by E. Klitzsch, R. Said, and E. Schrank, pp. 217-220, Von Dietrich Reimer, Berlin, Germany.

Sonntag, C., E. Klitzsch, E. P. Lohnert, E. M. El Shazly, K. O. Munnich, C. Junghans, U. Thorweihe, K. Weistroffer, and F. M. Swailem (1978), Paleoclimatic information from deuterium and oxygen-18 in carbon-14-dated north Saharian groundwaters, in Isotope Hydrology 1978: Proceedings of an International Symposium on Isotope Hydrology, pp. 569-580, Int. At. Energy Agency, Vienna.

Sturchio, N. C., et al. (2004), One million year old groundwater in the Sahara revealed by krypton- 81 and chlorine- 36 , Geophys. Res. Lett., 31, L05503, doi:10.1029/2003GL019234.

Stute, M., and P. Schlosser (2000), Atmospheric noble gases, in Environmental Tracers in Subsurface Hydrology, edited by P. G. Cook and A. L. Herczeg, pp. 349-377, Springer, New York.

Sultan, M., N. Sturchio, F. A. Hassan, M. A. R. Hamdan, A. M. Mahmood, Z. El Alfy, and T. Stein (1997), Precipitation source inferred from stable isotopic composition of Pleistocene groundwater and carbonate deposits in the Western Desert of Egypt, Quat. Res., 48, 29-37. 
Thorweihe, U. (1990), Nubian Aquifer system, in The Geology of Egypt, edited by R. Said, pp. 601-611, A. A. Balkema, Brookfield, Vt.

Tolstikhin, I., B. E. Lehmann, H. H. Loosli, and A. Gautschi (1996), Helium and argon isotopes in rocks, minerals, and related groundwaters: A case study in northern Switzerland, Geochim. Cosmochim. Acta, 60, 1497-1514.

Torgersen, T., and W. B. Clarke (1987), Helium accumulation in groundwater, III. Limits on helium transfer across the mantle-crust boundary beneath Australia and the magnitude of mantle degassing, Earth Planet. Sci. Lett., 84, 345-355.
Torgersen, T., M. A. Habermehl, F. M. Phillips, D. Elmore, P. Kubik, B. G. Jones, T. Hemmick, and H. E. Gove (1991), Chlorine 36 dating of very old groundwater 3. Further studies in the Great Artesian Basin, Australia, Water Resour Res., 27, 3201-3213.

Weaver, T. R. (2000), Stable isotopes of chlorine, in Environmental Tracers in Subsurface Hydrology, edited by P. G. Cook and A. L. Herczeg, pp. 492-498, Springer, New York.

Weiss, R. F. (1971), Solubility of helium and neon in water and seawater, J. Chem. Eng. Data, 16, 235-241. 